Prepared in cooperation with the Texas Water Development Board

\title{
A Historical Perspective on Precipitation, Drought Severity, and Streamflow in Texas during 1951-56 and 2011
}

Scientific Investigations Report 2013-5113

U.S. Department of the Interior

U.S. Geological Survey

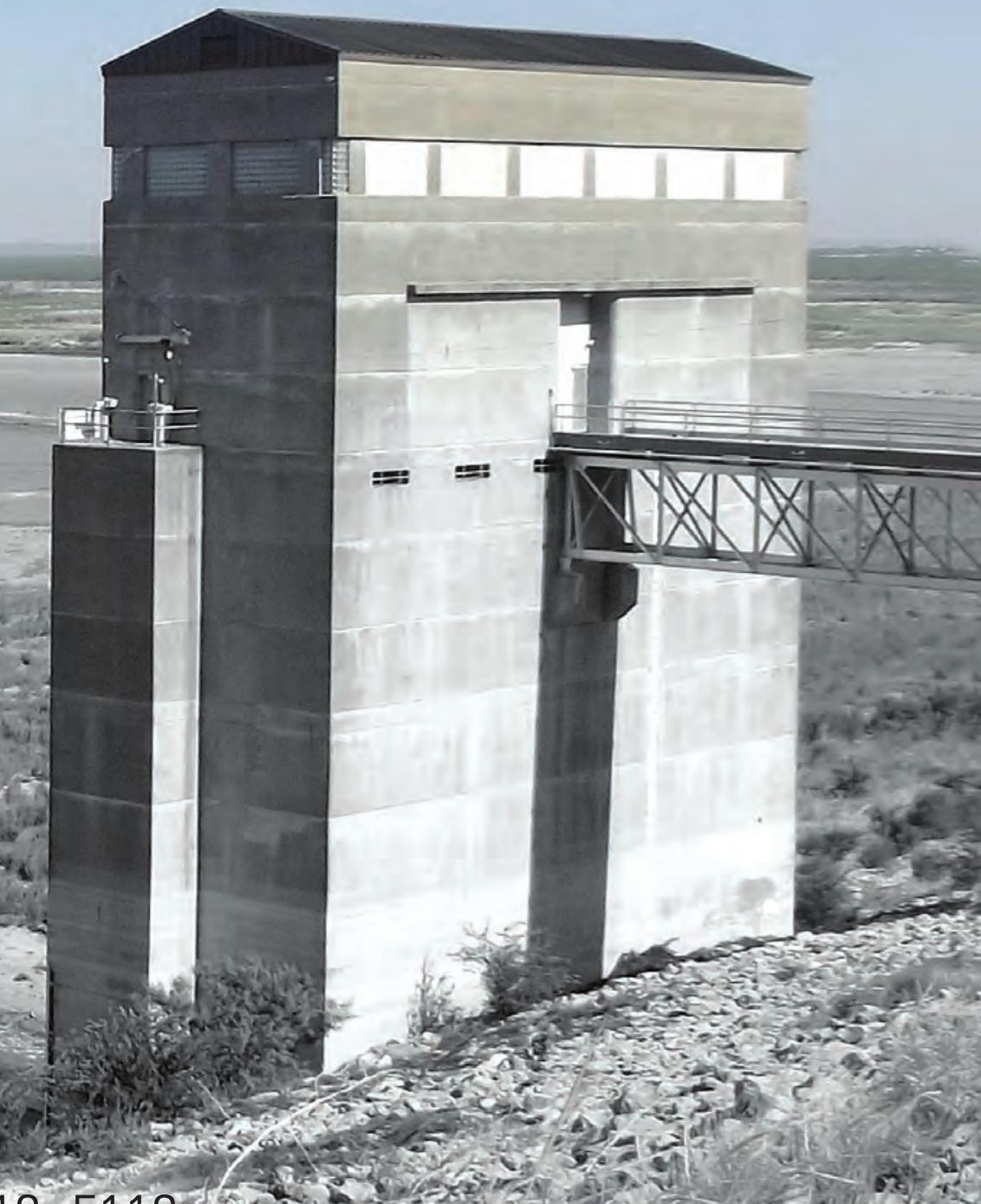


Front and Back Covers: Photograph of the dry lake bed at O.C. Fisher Lake at San Angelo, Texas, July 15, 2011. The lake is downstream from U.S. Geological Survey streamflow-gaging station 08134000 North Concho River near Carlsbad, Texas.

Back Cover: Inset photographs looking upstream from U.S. Geological Survey streamflow-gaging station 08148500 North Llano River near Junction, Texas (left) October 30, 2006, and (right) July 28, 2011. 


\section{A Historical Perspective on Precipitation, Drought Severity, and Streamflow in Texas during 1951-56 and 2011}

By Karl E. Winters

Prepared in cooperation with the Texas Water Development Board

Scientific Investigations Report 2013-5113 


\title{
U.S. Department of the Interior SALLY JEWELL, Secretary
}

\section{U.S. Geological Survey Suzette M. Kimball, Acting Director}

\author{
U.S. Geological Survey, Reston, Virginia: 2013
}

For more information on the USGS - the Federal source for science about the Earth, its natural and living resources, natural hazards, and the environment, visit http://www.usgs.gov or call 1-888-ASK-USGS.

For an overview of USGS information products, including maps, imagery, and publications, visit http://www.usgs.gov/pubprod

To order this and other USGS information products, visit http://store.usgs.gov

Any use of trade, firm, or product names is for descriptive purposes only and does not imply endorsement by the U.S. Government.

Although this information product, for the most part, is in the public domain, it also may contain copyrighted materials as noted in the text. Permission to reproduce copyrighted items must be secured from the copyright owner.

Suggested citation:

Winters, K.E., 2013, A historical perspective on precipitation, drought severity, and streamflow in Texas during 1951-56 and 2011: U.S. Geological Survey Scientific Investigations Report 2013-5113, 24 p., http://pubs.usgs.gov/ sir/2013/5113/. 


\section{Contents}

Abstract Introduction
Purpose and Scope
Previous Studies
Description of the Study Area
Methods
$\quad$ Precipitation
$\quad$ Streaght Severity
Precipitation
Drought Severity
Streamflown

\section{Figures}

1. Map showing locations of unregulated U.S. Geological Survey streamflow-gaging stations in Texas with complete records during the droughts of 1951-56 and 2011 .........3

2. Maps showing average annual precipitation in Texas; total precipitation during the 1956 calendar year; and the 2011 water year...

3. Graph showing magnitude and extent of the drought in Texas during 0ctober 1, 2010, to September 20, 2012.

4. Graphs showing monthly Palmer Drought Severity Index for Texas during 1900-2012 and annual runoff for Texas during 1901-2011.

5. Graph showing relation between Palmer Drought Severity Index and annual runoff for all U.S. Geological Survey streamflow-gaging stations in Texas during 1901-2011

6. Graphs showing annual mean streamflow at selected unregulated U.S. Geological Survey streamflow-gaging stations in Texas during 1951-56 and 2011

7. Graphs showing streamflow duration for selected unregulated U.S. Geological Survey streamflow-gaging stations in Texas for 1956, 2011, and the period of record.

8. Hydrograph showing streamflow duration and daily mean streamflow during January 2010 to September 2012 for U.S. Geological Survey streamflow-gaging station 07233500 Palo Duro Creek near Spearman, Texas.

9. Hydrograph showing streamflow duration and daily mean streamflow during January 2010 to September 2012 for U.S. Geological Survey streamflow-gaging station 07343000 North Sulphur River near Cooper, Texas

10. Hydrograph showing streamflow duration and daily mean streamflow during January 2010 to September 2012 for U.S. Geological Survey streamflow-gaging station 07346070 Little Cypress Creek near Jefferson, Texas 


\section{Figures-Continued}

11. Hydrograph showing streamflow duration and daily mean streamflow during January 2010 to September 2012 for U.S. Geological Survey streamflow-gaging station 08041500 Village Creek near Kountze, Texas .

12. Hydrograph showing streamflow duration and daily mean streamflow during January 2010 to September 2012 for U.S. Geological Survey streamflow-gaging station 08068500 Spring Creek near Spring, Texas ....

13. Hydrograph showing streamflow duration and daily mean streamflow during January 2010 to September 2012 for U.S. Geological Survey streamflow-gaging station 08070000 East Fork San Jacinto River near Cleveland, Texas

14. Hydrograph showing streamflow duration and daily mean streamflow during January 2010 to September 2012 for U.S. Geological Survey streamflow-gaging station 08070500 Caney Creek near Splendora, Texas.

15. Hydrograph showing streamflow duration and daily mean streamflow during January 2010 to September 2012 for U.S. Geological Survey streamflow-gaging station 08071000 Peach Creek at Splendora, Texas.

16. Hydrograph showing streamflow duration and daily mean streamflow during January 2010 to September 2012 for U.S. Geological Survey streamflow-gaging station 08134000 North Concho River near Carlsbad, Texas

17. Hydrograph showing streamflow duration and daily mean streamflow during January 2010 to September 2012 for U.S. Geological Survey streamflow-gaging station 08148500 North Llano River near Junction, Texas

18. Hydrograph showing streamflow duration and daily mean streamflow during January 2010 to September 2012 for U.S. Geological Survey streamflow-gaging station 08150000 Llano River near Junction, Texas.

19. Hydrograph showing streamflow duration and daily mean streamflow during January 2010 to September 2012 for U.S. Geological Survey streamflow-gaging station 08164000 Lavaca River near Edna, Texas.

20. Hydrograph showing streamflow duration and daily mean streamflow during January 2010 to September 2012 for U.S. Geological Survey streamflow-gaging station 08166000 Johnson Creek near Ingram, Texas.

21. Hydrograph showing streamflow duration and daily mean streamflow during January 2010 to September 2012 for U.S. Geological Survey streamflow-gaging station 08167500 Guadalupe River near Spring Branch, Texas.

22. Hydrograph showing streamflow duration and daily mean streamflow during January 2010 to September 2012 for U.S. Geological Survey streamflow-gaging station 08171000 Blanco River at Wimberley, Texas

23. Hydrograph showing streamflow duration and daily mean streamflow during January 2010 to September 2012 for U.S. Geological Survey streamflow-gaging station 08189500 Mission River at Refugio, Texas

24. Hydrograph showing streamflow duration and daily mean streamflow during January 2010 to September 2012 for U.S. Geological Survey streamflow-gaging station 08195000 Frio River at Concan, Texas

25. Hydrograph showing streamflow duration and daily mean streamflow during January 2010 to September 2012 for U.S. Geological Survey streamflow-gaging station 08198000 Sabinal River near Sabinal, Texas

26. Hydrograph showing streamflow duration and daily mean streamflow during January 2010 to September 2012 for U.S. Geological Survey streamflow-gaging station 08205500 Frio River near Derby, Texas 


\section{Tables}

1. Classification of drought severity by the Palmer Drought Severity Index and by the Drought Monitor........

2. Unregulated U.S. Geological Survey streamflow-gaging stations in Texas with complete record during the droughts of 1951-56 and 2011.

3. Twelve-month statewide average precipitation for selected water years in Texas.........7

4. Monthly statewide Palmer Drought Severity Index (PDSI) during the 1951-56 and 2011 droughts in Texas...

\section{Conversion Factors}

Inch/Pound to SI

\begin{tabular}{lll}
\hline \multicolumn{1}{c}{ Multiply } & \multicolumn{1}{c}{ By } & \multicolumn{1}{c}{ To obtain } \\
\hline inch (in) & \multicolumn{1}{c}{ Length } & \\
foot $(\mathrm{ft})$ & 2.54 & centimeter $(\mathrm{cm})$ \\
mile $(\mathrm{mi})$ & 0.3048 & meter $(\mathrm{m})$ \\
\hline \multicolumn{3}{c}{ Area } \\
\hline square mile $\left(\mathrm{mi}^{2}\right)$ & 1.609 & kilometer $(\mathrm{km})$ \\
\hline & 2.590 & \\
\hline cubic foot per second $\left(\mathrm{ft}^{3} / \mathrm{s}\right)$ & Flow rate & \\
\hline
\end{tabular}

Vertical coordinate information is referenced to the North American Vertical Datum of 1988 (NAVD 88).

Horizontal coordinate information is referenced to the North American Datum of 1983 (NAD 83).

A water year is the 12-month period October 1 through September 30 designated by the calendar year in which it ends. 



\title{
A Historical Perspective on Precipitation, Drought Severity, and Streamflow in Texas during 1951-56 and 2011
}

\author{
By Karl E. Winters
}

\section{Abstract}

The intense drought throughout Texas during 2011 resulted in substantial declines in streamflow. By April 2011, nearly all of the State was experiencing severe to extreme drought according to data from the University of NebraskaLincoln Drought Monitor. By the end of July 2011, more than 75 percent of the State was experiencing exceptional drought. The worst of the drought occurred around October 4, 2011, when 97 percent of Texas was suffering from extreme to exceptional drought. The historical drought of 1951-56 has long been used by water-resource managers, engineers, and scientists as a point of reference for water-supply planning. A comparison of drought conditions during the 2011 water year (October 1, 2010, through September 30, 2011) to the historical drought of 1951-56 from a hydrologic perspective serves as an additional reference for water-supply planning.

A record low statewide average annual precipitation of 11.27 inches for the period 1895-2011 was recorded during the 2011 water year; the prior record low statewide average precipitation was 13.91 inches during the 1956 water year. The statewide monthly Palmer Drought Severity Index (PDSI) declined to -7.93 during September 2011, which was larger in magnitude than the statewide PDSI during any droughtaffected month in the 1950s.

Annual mean streamflow and streamflow-duration curves for the 1951-56 and 2011 water years were assessed for 19 unregulated U.S. Geological Survey (USGS) streamflowgaging stations. At eight of these streamflow-gaging stations, the annual mean streamflow was lower in 2011 than for any year during 1951-56; many of these stations are located in eastern Texas. Annual mean streamflows for streamflow-gaging stations in the Guadalupe, Blanco, and upper Frio River Basins were lower in 1956 than in 2011. The streamflow-duration curves for many streamflow-gaging stations indicate a lack of (or diminished) storm runoff during 2011. Low streamflows (those exceeded 90 to 95 percent of days) were lower for 1956 than for 2011 at seven streamflowgaging stations. For most of these stations, the lowest of the low streamflows during 1951-56 occurred in 1956. During March to September 2011, record daily lows were measured at USGS streamflow-gaging station 08041500 Village Creek near Kountze, Tex., which has more than 70 years of record. Many other USGS streamflow-gaging stations in Texas started the 2011 water year with normal streamflow but by the end of the water year were flowing at near-record lows.

\section{Introduction}

In 2011, there was a severe drought in Texas, and scant precipitation fell throughout most of the State. Record high temperatures during June through August 2011 (Dallas Morning News, 2011) combined with the scant precipitation to help produce record low streamflows throughout the State. By August 4, 2011, the precipitation deficit was so severe that State Climatologist John Nielsen-Gammon declared 2011 to be the worst 1-year drought on record in Texas (Texas A\&M University, 2011). A record low statewide average annual precipitation of 11.27 inches for the period 1895-2011 was recorded during the 2011 water year; the prior record low statewide average precipitation was 13.91 inches during the 1956 water year. (A water year is the 12-month period from October 1 through September 30 designated by the calendar year in which it ends.)

Drought conditions prevailed in Texas from 1947 to 1957, with the most severe years of drought occurring in the 1950s, providing historical perspective for the 2011 drought. The years of 1951 through 1956 in particular have long been used by water-resource managers, engineers, and scientists as a point of reference for water-supply planning (Texas Water Development Board, 2013). A comparison of the 2011 drought to the drought of 1951-56 from a hydrologic perspective serves as an additional reference for water-supply planning. Accordingly, in 2012, the U.S. Geological Survey (USGS), in cooperation with the Texas Water Development Board (TWDB), assessed the effects of the 1951-56 and 2011 droughts from a hydrologic perspective. 


\section{Purpose and Scope}

The purpose of this report is to document precipitation, drought severity, and streamflow in Texas during the droughts of 1951-56 and 2011. Isohyetal maps are presented for the purpose of comparing normal annual precipitation in Texas and total precipitation during the 1956 and 2011 water years. The magnitude and extent of the 2011 drought in Texas are described by using the Palmer Drought Severity Index (PDSI) (Palmer, 1965) and by using the Drought Monitor's drought severity classification (University of Nebraska-Lincoln, 2012). For historical perspective on the 1951-56 and 2011 droughts, precipitation, drought severity, and statewide runoff data were analyzed from 1895-2011, 1900-2011, and 1901-2011, respectively. Annual mean streamflows for 19 unregulated streamflow-gaging stations in Texas are presented for the 1951-56 and 2011 water years, and streamflow-duration curves are presented for these stations for 1956 and 2011. Comparisons are made between the 1951-56 and 2011 droughts. Drought severity is discussed using (aggregate) statewide data and not with respect to climatic divisions within the State. This report does not discuss the effects of drought on lakes or groundwater levels or the effects of drought on agriculture, water quality, or habitat.

\section{Previous Studies}

The Texas State Climatologist reported on precipitation deficits during the 2011 drought (Nielsen-Gammon, 2011). That report details the use of a Standardized Precipitation Index (SPI) (U.S. Department of Commerce, National Climatic Data Center, 2012) and provides maps showing the SPI for each county in Texas during October 2010 to October 2011. The SPI relates precipitation recorded during a specific period to the historical precipitation record at a given location. Texas has 10 climatic divisions (U.S. Department of Agriculture, National Agriculture Statistics Service, 2013) recognized by climatologists for purposes of data aggregation and scientific investigations. The report by Nielsen-Gammon (2011) also presents PDSI values throughout Texas for 13 drought periods during 1900-2011.
Thomas and others (1963) reported on the effects of drought in central and south Texas during 1942-56 and noted that many streams in central Texas formerly regarded as perennial had ceased flowing during drought years. Nace and Pluhowski (1965) reported on the drought of the 1950s in Colorado, Iowa, Kansas, Missouri, New Mexico, Oklahoma, and Texas. Those authors noted that Texas had the greatest precipitation deficiency in the United States during the 1951-56 drought, and that discharge on many unregulated streams in Texas diminished to record-breaking lows, including no-flow conditions. Those authors also noted that, as early as 1953, streamflow in the Texas Panhandle region returned to normal.

Asquith and others (2007) reported the occurrence of zero flows at USGS streamflow-gaging stations in Texas. Graphs of the annual percentage of zero flow through 2003 are presented for each station. Asquith and Heitmuller (2008) reported trends in mean and harmonic mean streamflows for 620 streamflow-gaging stations in Texas. Although accounting for changes in streamflow over time was beyond the scope of this report, the reports by Asquith and others (2007) and Asquith and Heitmuller (2008) may help to inform the reader as to whether streamflows at a particular streamflow-gaging station may have changed over time.

\section{Description of the Study Area}

The study area is Texas (fig. 1). Average annual precipitation in Texas ranges from about 9 inches in the western part of the State to more than 50 inches in the southeastern part of the State (fig. 2A). Statewide average annual precipitation is 27.95 inches. Figure 1 depicts the location of the long-term unregulated streamflow-gaging stations with complete record for the 1951-56 and 2011 water years. These streamflow-gaging stations are generally in south-central and eastern Texas, with one station in the Texas Panhandle (fig. 1). Relatively few perennial streams exist in western Texas, and no USGS streamflow-gaging stations in that part of the State have complete streamflow record for the periods 1951-56 and 2011. Streamflows at stations on the Colorado, Brazos, and Trinity Rivers are regulated and not discussed in this report. 


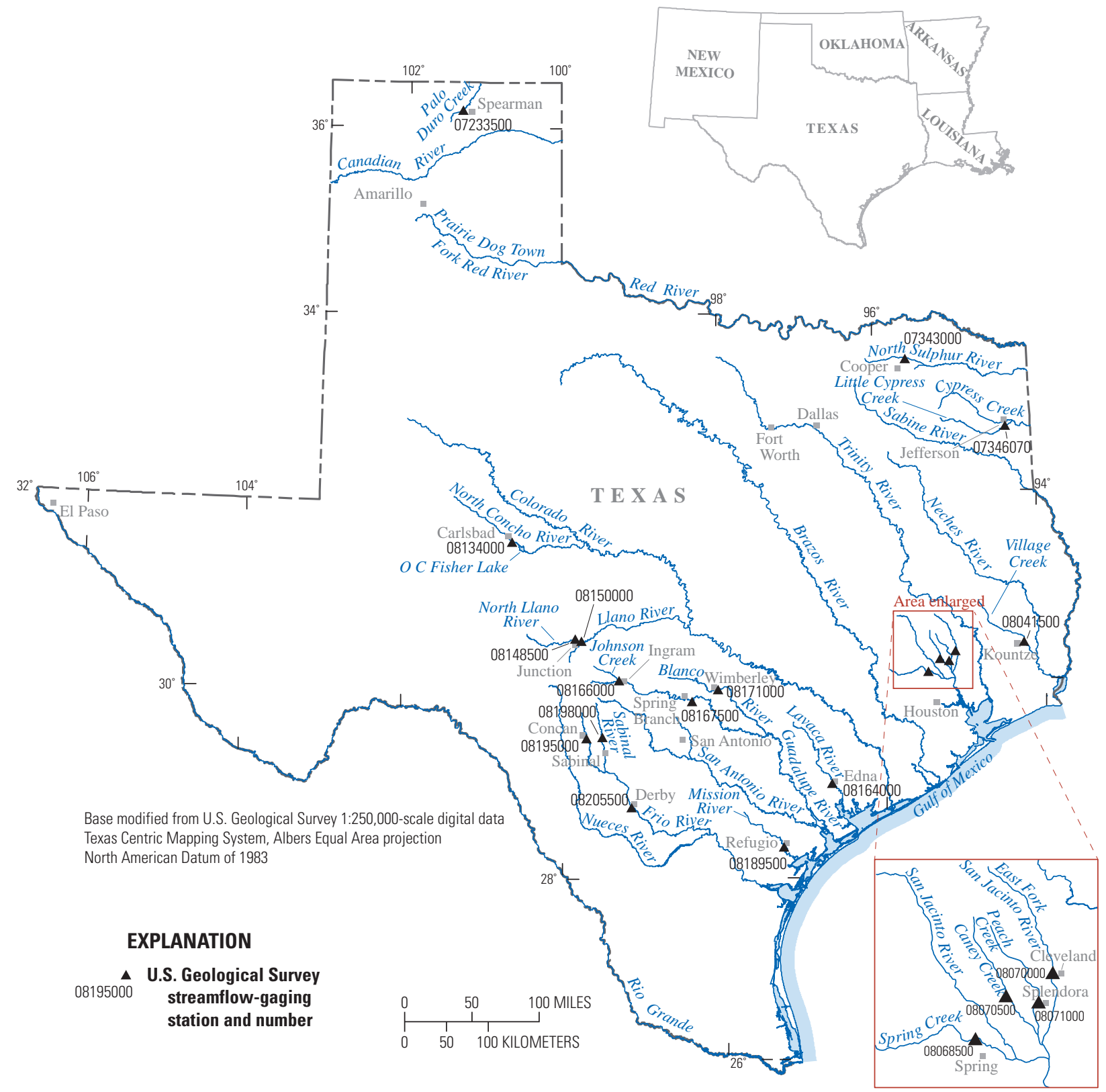

Figure 1. Locations of unregulated U.S. Geological Survey streamflow-gaging stations in Texas with complete records during the droughts of $1951-56$ and 2011. 


\section{A. Average annual precipitation}

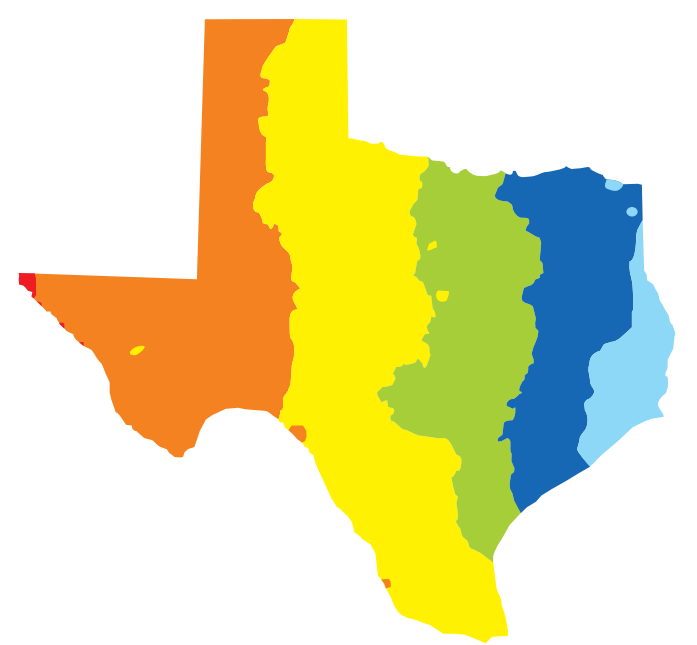

B. Total precipitation during 1956 calendar year

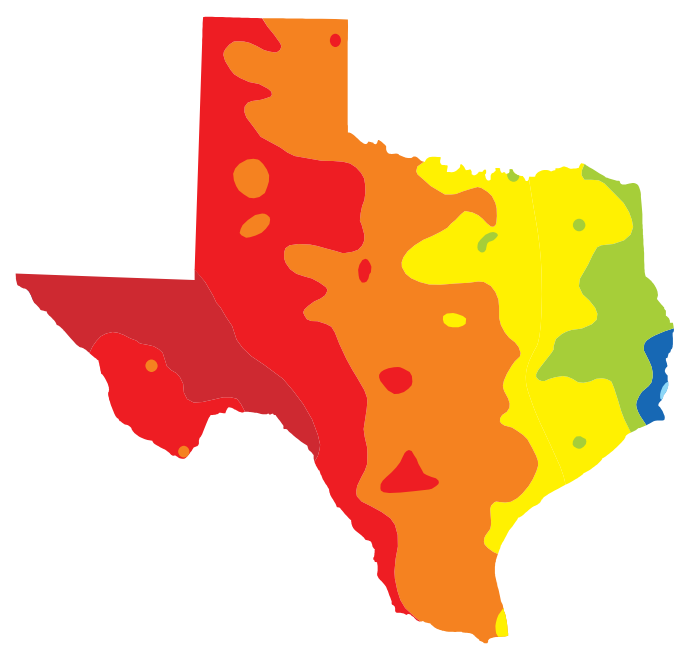

C. Total precipitation during 2011 water year (October 1, 2010-September 30, 2011)
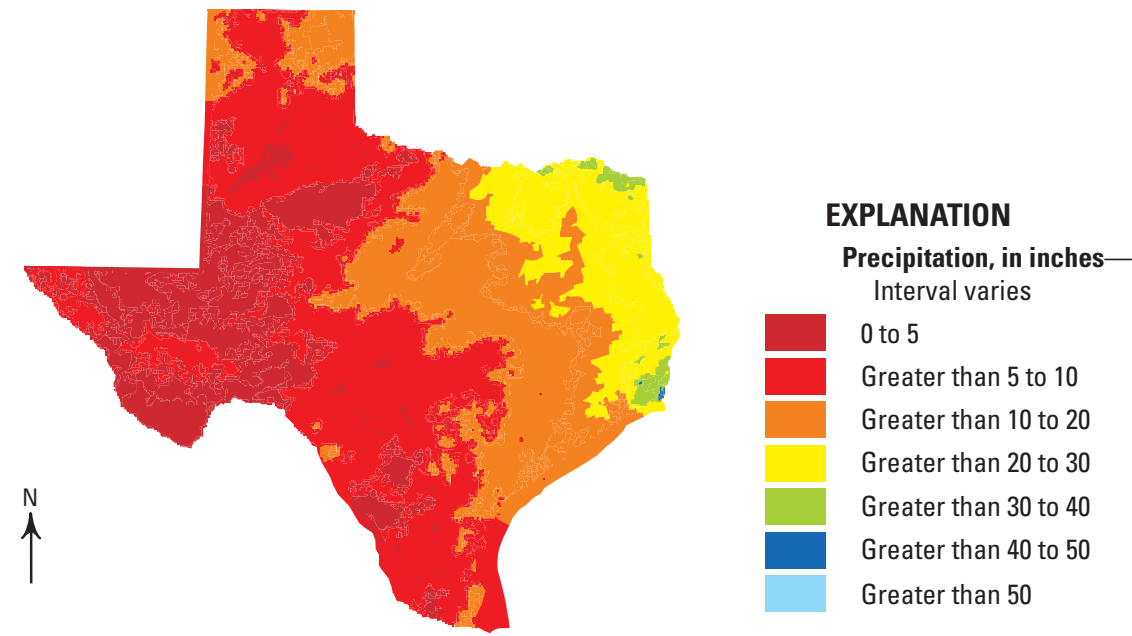

Figure 2. $A$, Average annual precipitation in Texas (National Weather Service, 2012); total precipitation during $B$, the 1956 calendar year (modified from U.S. Department of Commerce, Weather Bureau, 1957); and $C$, the 2011 water year (National Weather Service, 2012). 


\section{Methods}

Precipitation, drought severity, and streamflow were summarized for the droughts of 1951-56 and 2011 by using previously published data obtained from various sources. The U.S. Department of Commerce, the Drought Monitor, and the U.S. Geological Survey were the primary sources of these data. All of the sources of data are described in detail in the following discussions pertaining to precipitation, drought severity and streamflow.

\section{Precipitation}

Statewide average annual precipitation data for Texas were obtained from the National Climatic Data Center (NCDC) (U.S. Department of Commerce, National Climatic Data Center, 2012) for the years 1895-2011. The 12-month statewide averages were ranked by water year from lowest to highest to assess the 1951-56 and 2011 precipitation amounts and to compare those amounts to the average annual precipitation. Additionally, isohyetal maps showing lines of equal precipitation (Jain and Singh, 2005) are presented in figure 2 showing average annual precipitation in Texas and total precipitation during calendar year 1956 and water year 2011. Isohyetal maps showing average annual precipitation and total precipitation during the 2011 water year were obtained from the National Weather Service's
Advanced Hydrologic Prediction Service (National Weather Service, 2012). The isohyetal map for the 1956 calendar year was obtained from the Weather Bureau (now the National Weather Service) climatological data summary for 1956 (U.S. Department of Commerce, 1957).

\section{Drought Severity}

Two drought severity classifications (table 1) were used to assess the intensity of drought in Texas during 1951-56 and 2011. The PDSI is a quantitative assessment of soil moisture based on precipitation and temperature data (Palmer, 1965). PDSI values greater than 0.49 corresponding to wetter than normal conditions are not shown in table 1 . The NCDC calculates monthly and annual PDSI values for each State and for each climatic division. Texas has 10 climatic divisions (U.S. Department of Agriculture, National Agriculture Statistics Service, 2013) recognized by climatologists for purposes of data aggregation and scientific assessment; assessment of drought severity by climatic division is beyond the scope of this report. The Drought Monitor, a public service operated by the University of Nebraska-Lincoln, classifies drought into five qualitative categories (table 1; University of Nebraska-Lincoln, 2012). Areal percentages of Texas corresponding to the various drought categories at weekly intervals during 2011 were obtained from the Drought Monitor.

Table 1. Classification of drought severity by the Palmer Drought Severity Index and by the Drought Monitor.

[Each classification system is different, and the classification indexes and categories are not equivalent. Palmer Drought Severity Index from Palmer, 1965; Drought Monitor from University of Nebraska-Lincoln, 2012]

\begin{tabular}{|c|c|c|c|}
\hline \multicolumn{2}{|c|}{ Palmer Drought Severity Index classifications } & \multicolumn{2}{|c|}{ Drought Monitor classifications } \\
\hline $\begin{array}{l}\text { Palmer Drought } \\
\text { Severity Index }\end{array}$ & Class & $\begin{array}{l}\text { Drought } \\
\text { category }\end{array}$ & Description \\
\hline 0.49 to -0.49 & Near normal & & \\
\hline-0.50 to -0.99 & Incipient drought & D0 & Abnormally dry \\
\hline-1.00 to -1.99 & Mild drought & D1 & Moderate drought \\
\hline-2.00 to -2.99 & Moderate drought & D2 & Severe drought \\
\hline-3.00 to -3.99 & Severe drought & D3 & Extreme drought \\
\hline Less than -3.99 & Extreme drought & D4 & Exceptional drought \\
\hline
\end{tabular}




\section{Streamflow}

Streamflow data for 19 unregulated USGS

streamflow-gaging stations (fig. 1; table 2) were used to assess the effects of drought during 1951-56 and 2011. These data include annual and daily mean streamflow obtained from the USGS National Water Information System (NWIS; U.S. Geological Survey, 2012a). Only stations with complete record during 1951-56 and 2011 were used in this study. Additionally, stations flagged as "regulated" in the NWIS peak-flow file (http://nwis.waterdata.usgs.gov/tx/nwis/ peak) were not included in the analyses. As described by Asquith (2001), two commonly used simple classification schemes consider regulated stations as (1) those where at least 10 percent of the drainage area of the basin is affected or controlled by reservoirs, or (2) regulated to the degree that annual peak streamflows are likely to be affected. USGS hydrologists assign a numeric code of " 6 " in the peak-flow file to designate peak streamflows affected by regulation.

USGS station 07233500 Palo Duro Creek near Spearman, Tex. (hereinafter the Palo Duro gage), has a small diversion upstream for irrigation. Data for this station are included in this report because no other unregulated station is available in the Texas Panhandle with complete record during 1951-56 and 2011. In this report, USGS streamflow-gaging stations are frequently referred to by their station number followed by their station name (table 2).

Annual runoff, in inches (computed as the average flow per unit area for streamflow-gaging stations in Texas), for the State of Texas for the period 1901-2011 was obtained from the USGS WaterWatch Web page (U.S. Geological Survey, 2012b). This runoff is based on the entire network of USGS streamflow-gaging stations in Texas, including streams that are affected by regulation. Compared to annual runoff values computed since about 1925, annual runoff values computed from about 1901 to about 1924 are likely to be much less accurate because few stations were in operation before 1924. An assessment of the effect of the number of streamflow-gaging stations on the accuracy of statewide runoff computations is beyond the scope of this report.

Streamflow-duration curves (Searcy, 1959) describe the percentage of time that a given streamflow was equaled or exceeded at a site. The median streamflow is exceeded 50 percent of the time. Streamflow values exceeded only 5 or 10 percent of the time usually represent storm runoff, and a steeply-sloped curve indicates a greater magnitude and frequency of storm flows. On the drier end of the spectrum, streamflows exceeded 95 percent of the time typically are

Table 2. Unregulated U.S. Geological Survey streamflow-gaging stations in Texas with complete record during the droughts of 1951-56 and 2011.

\begin{tabular}{clcc}
\hline $\begin{array}{c}\text { Station } \\
\text { number }\end{array}$ & \multicolumn{1}{c}{ Station name } & $\begin{array}{c}\text { Contributing } \\
\text { drainage area } \\
\text { (square miles) }\end{array}$ & Period of record \\
\hline 07233500 & Palo Duro Creek near Spearman, Tex. & 556 & $1945-79,1999-2011$ \\
07343000 & North Sulphur River near Cooper, Tex. & 276 & $1950-2011$ \\
07346070 & Little Cypress Creek near Jefferson, Tex. & 675 & $1946-2011$ \\
08041500 & Village Creek near Kountze, Tex. & 860 & $1939-2011$ \\
08068500 & Spring Creek near Spring, Tex. & 409 & $1939-2011$ \\
08070000 & East Fork San Jacinto River near Cleveland, Tex. & 325 & $1939-2011$ \\
08070500 & Caney Creek near Splendora, Tex. & 105 & $1944-2011$ \\
08071000 & Peach Creek at Splendora, Tex. & 117 & $1944-77,1999-2011$ \\
08134000 & North Concho River near Carlsbad, Tex. & 1,191 & $1924-2011$ \\
08148500 & North Llano River near Junction, Tex. & 914 & $1916-77,2001-2011$ \\
08150000 & Llano River near Junction, Tex. & 1,849 & $1916-93,1998-2011$ \\
08164000 & Lavaca River near Edna, Tex. & 817 & $1938-2011$ \\
08166000 & Johnson Creek near Ingram, Tex. & 114 & $1941-59,1962-93$, \\
& & & $1999-2011$ \\
08167500 & Guadalupe River near Spring Branch, Tex. & 1,315 & $1922-2011$ \\
08171000 & Blanco River at Wimberley, Tex. & 355 & $1924-26,1928-2011$ \\
08189500 & Mission River at Refugio, Tex. & 690 & $1939-2011$ \\
08195000 & Frio River at Concan, Tex. & 389 & $1931-2011$ \\
08198000 & Sabinal River near Sabinal, Tex. & 206 & $1943-2011$ \\
08205500 & Frio River near Derby, Tex. & 3,429 & $1915-2011$ \\
\hline & & & \\
\hline
\end{tabular}


indicative of low flows that occur in Texas during August and September. Streamflow-duration curves were computed for the 19 unregulated USGS streamflow-gaging stations (table 2), for water years 1956 and 2011, and (for comparison) for the period of record (1956 was selected to represent the 1951-56 drought for the streamflow-duration assessment). Streamflowduration curves were based on daily mean streamflow data obtained from NWIS and computed by using the USGS Automated Data Processing System (U.S. Geological Survey, 2008). Computations included daily mean streamflows that were equaled or exceeded 5, 10, 25, 50, 75, 90, and 95 percent of the time.

Additionally, daily streamflow-duration data for the period of record for each of the 19 unregulated USGS streamflow-gaging stations in table 2 were obtained from USGS WaterWatch (U.S. Geological Survey, 2012b). These data indicate the percentage of time that a given streamflow was not exceeded for a specific date (for example, during all of the August 15ths in the period of record).

\section{Historical Perspective on Precipitation, Drought Severity, and Streamflow in Texas during 1951-56 and 2011}

The magnitude of the 2011 drought in Texas is best understood by comparing selected metrics of drought from 1951-56 with those measured in 2011. Precipitation, drought severity, and streamflow are the metrics used to gain a historical perspective on the 2011 severe drought compared to drought conditions during 1951-56.

\section{Precipitation}

Statewide average annual precipitation is 27.95 inches. Statewide average precipitation for the 1951-56 and 2011 water years is shown in table 3 . Also shown is the ranking (lowest to highest) for each of those years relative to the period 1895-2011. Prior to 2011, the driest 1-year period was the 1956 water year, when Texas received only about 50 percent of its normal annual precipitation. During the 2011 water year, Texas received only about 40 percent of its normal annual precipitation.

Isohyetal maps of total precipitation in Texas during 1956 and 2011 are shown in figures $2 B$ and $2 C$, respectively. Figure 2C highlights the extent of the 2011 drought when large parts of Texas received less than 10 inches of precipitation during the year. During 2011, few storms in Texas generated more than about an inch of precipitation (National Weather Service, 2012); thus, a larger fraction of the precipitation evaporated or entered the ground as infiltration rather than contributing to streamflow. Asquith and Roussel (2007) reported the initial abstraction (the amount of
Table 3. Twelve-month statewide average precipitation for selected water years in Texas.

[Data source: U.S. Department of Commerce, National Climatic Data Center, 2012]

\begin{tabular}{ccc}
\hline Period & $\begin{array}{c}\text { Precipitation } \\
\text { (inches) }\end{array}$ & $\begin{array}{c}\text { Rank } \\
\text { (1895-2011) }\end{array}$ \\
\hline October 1950-September 1951 & 18.98 & 6 \\
October 1951-September 1952 & 19.88 & 9 \\
October 1952-September 1953 & 22.67 & 20 \\
October 1953-September 1954 & 19.59 & 8 \\
October 1954-September 1955 & 24.89 & 37 \\
October 1955-September 1956 & 13.91 & 2 \\
October 2010-September 2011 & 11.27 & 1 \\
\hline
\end{tabular}

precipitation that infiltrates before any runoff is generated) for 92 watersheds in Texas. The median initial abstraction for 41 undeveloped watersheds was 1.1 inches, which indicates storms producing 1.1 inches or less rainfall likely do not generate runoff. Because the analysis by Asquith and Roussel (2007) was performed only for storms that generated runoff, larger amounts of initial abstraction may have occurred but not detected during periods of extreme soil moisture deficits such as the 2011 drought (William Asquith, U.S. Geological Survey, written commun., 2012).

\section{Drought Severity}

Figure 3 depicts the magnitude and extent of drought in Texas during the 2011 water year by using data obtained from the Drought Monitor (University of Nebraska-Lincoln, 2012) from October 1, 2010, to September 20, 2012. On October 1, 2010, parts of Texas were abnormally dry, but none of Texas was classified as being in a drought. By April 2011, nearly all of Texas was in a severe to extreme drought, and by the end of July 2011, more than 75 percent was in an exceptional drought. Figure 3 depicts the widespread extent of drought in Texas during the 2011 water year in contrast to water years of 2010 and 2012 when drought conditions were less prevalent. The greatest areal extent of the drought occurred a few days after the end of the 2011 water year, around October 4, 2011, when 97 percent of Texas was characterized as in an extreme to exceptional drought.

Statewide monthly values of the PDSI during the droughts of 1951-56 and 2011 are listed in table 4 (U.S. Department of Commerce, National Climatic Data Center, 2012). Between August 1951 and November 1952, 14 of 16 monthly statewide PDSI values indicated extreme drought (PDSI less than -3.99; table 1), and extreme drought also occurred during the entire 1955 and 1956 water years. The lowest statewide PDSI indicating the most severe drought conditions during the period 1951-56 was -7.8, which occurred September 1956. 


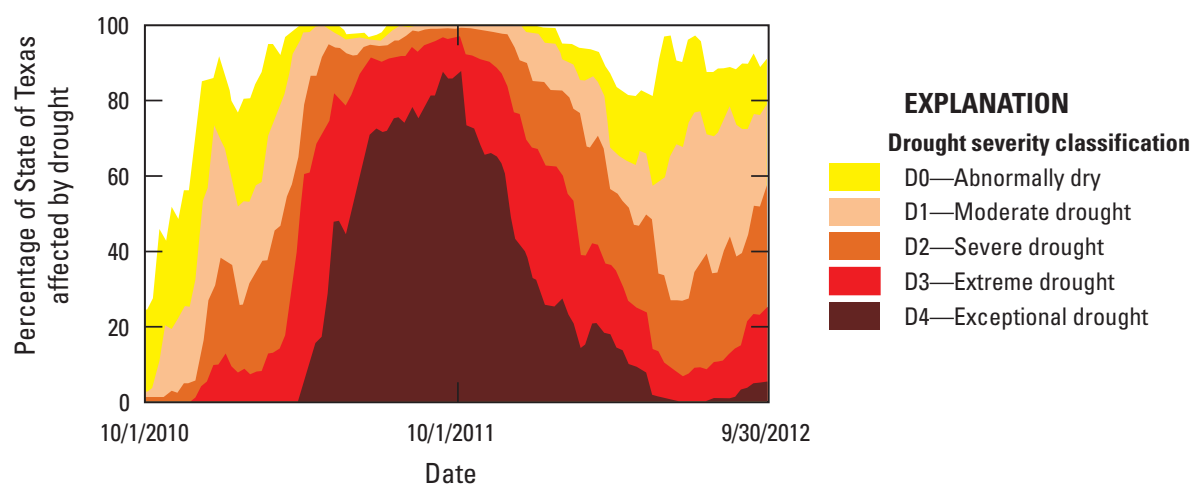

Figure 3. Magnitude and extent of the drought in Texas during October 1, 2010, to September 20, 2012. Data courtesy of the Drought Monitor (University of Nebraska-Lincoln, 2012).

Table 4. Monthly statewide Palmer Drought Severity Index (PDSI) during the 1951-56 and 2011 droughts in Texas.

[Data source: U.S. Department of Commerce, National Climatic Data Center, 2012]

\begin{tabular}{lccccccc}
\hline \multirow{2}{*}{ Month } & \multicolumn{7}{c}{ Water year } \\
\cline { 2 - 8 } & $\mathbf{1 9 5 1}$ & $\mathbf{1 9 5 2}$ & $\mathbf{1 9 5 3}$ & $\mathbf{1 9 5 4}$ & $\mathbf{1 9 5 5}$ & $\mathbf{1 9 5 6}$ & $\mathbf{2 0 1 1}$ \\
\hline October & -0.95 & -4.24 & -5.75 & -2.98 & -5.30 & -4.31 & -0.71 \\
November & -1.64 & -4.28 & -4.46 & -2.95 & -5.21 & -4.55 & -1.17 \\
December & -2.38 & -4.60 & -3.70 & -2.69 & -5.42 & -4.82 & -1.75 \\
January & -2.81 & -5.14 & -3.88 & -2.87 & -5.26 & -4.90 & -1.84 \\
February & -3.04 & -5.25 & -3.71 & -3.66 & -4.88 & -4.76 & -2.35 \\
March & -2.70 & -4.87 & -3.55 & -4.02 & -4.97 & -5.01 & -3.19 \\
April & -3.05 & -3.93 & -3.17 & -3.88 & -5.27 & -5.19 & -4.19 \\
May & -3.10 & -3.62 & -3.05 & -3.44 & -5.01 & -5.72 & -5.08 \\
June & -3.27 & -4.53 & -3.86 & -4.09 & -5.08 & -6.54 & -6.24 \\
July & -3.89 & -4.69 & -4.02 & -4.89 & -4.92 & -7.05 & -7.08 \\
August & -4.49 & -5.55 & -3.29 & -5.23 & -4.43 & -7.30 & -7.72 \\
September & -4.01 & -5.42 & -3.74 & -5.91 & -4.25 & -7.80 & -7.93 \\
\hline
\end{tabular}

The statewide monthly PDSI declined to -7.93 during September 2011, which was larger in magnitude than the PDSI values recorded for any drought-affected month during the 1950 s. Also noteworthy is that it only took 12 months from the onset of the 2011 drought for the statewide PDSI to drop below -7; whereas, it took about 6 years from the onset of the 1950s drought until the statewide monthly PDSI values dropped below -7 .
For a historical perspective, monthly statewide PDSI data for the period 1900-2012 are shown in figure 4A. The data show both the severity and duration of droughts in Texas. Prolonged periods of drought occurred during 1909-11, 1917-18, 1951-56, and 1963-64. Cleaveland and others (2011) used dendrochronology and other methods to evaluate drought in several parts of Texas. According to Cleaveland and others $(2011$, p. 54) "this and previous studies indicate that severe decadal-scale droughts have occurred in Texas at least once a century since the 1500 s." 


\section{Streamflow}

The USGS WaterWatch Web page (U.S. Geological Survey, 2012b) displays annual mean runoff, in inches, for each State. Annual runoff for Texas during 1901-2011 is shown in figure $4 \mathrm{~B}$. The lowest 4 years and the respective runoff depths are 1917 (0.61 inches), 1918 (0.66 inches), 1956 (0.71 inches), and 2011 (0.49 inches). These values represent annual runoff from gaged basins only. Prior to 1924, fewer than 40 streamflow-gaging stations were operated in Texas; therefore, statewide runoff computed for those years may not be representative of the actual statewide runoff. Comparison of figures $4 A$ and $\underline{4 B}$ shows the effect of drought on runoff. Annual statewide values of PDSI were computed as the average of the monthly (October to September) PDSI values; the relation between the annual PDSI and annual runoff for Texas is shown in figure 5 . The annual PDSI values for water years 1956 and 2011 were -5.66 and -4.10 , respectively; however, statewide runoff in 2011 was less than during 1956.
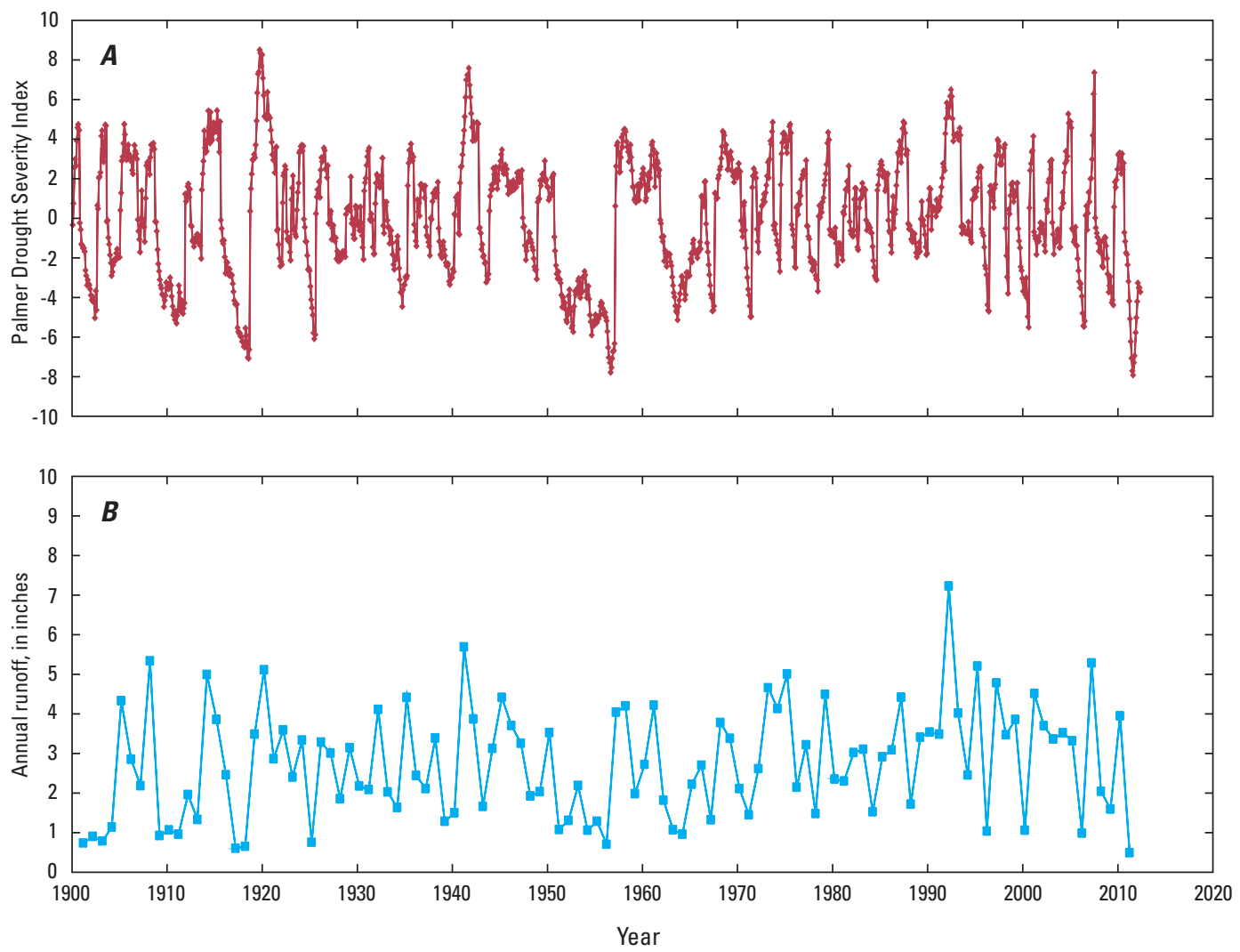

Figure 4. A, Monthly Palmer Drought Severity Index for Texas during 1900-2012 (U.S. Department of Commerce, National Climatic Data Center, 2012) and $B$, annual runoff for Texas during 1901-2011 (U.S. Geological Survey, 2012b). 


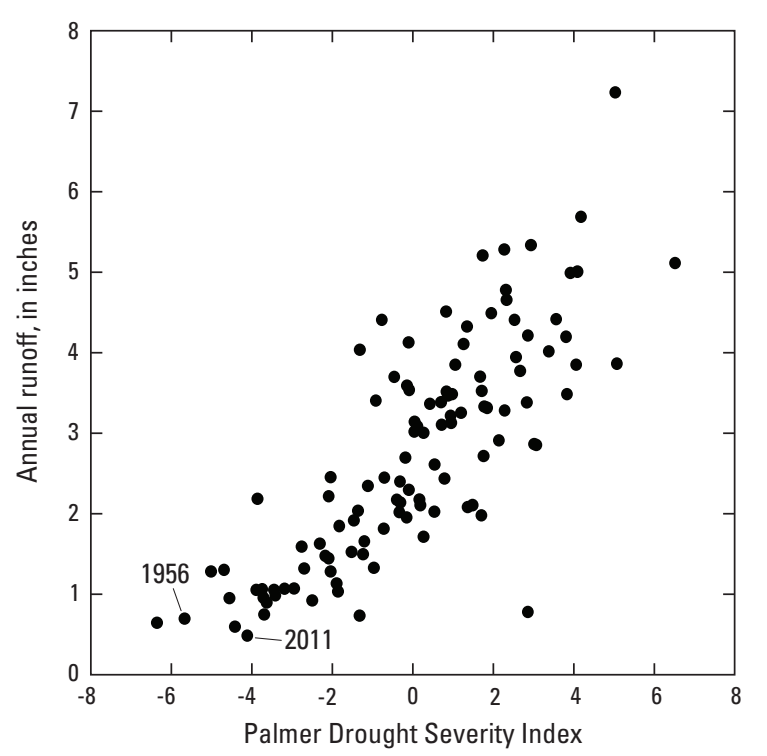

Figure 5. Relation between Palmer Drought Severity Index (U.S. Department of Commerce, National Climatic Data Center, 2012) and annual runoff for all U.S.

Geological Survey streamflow-gaging stations in Texas during 1901-2011 (U.S. Geological Survey, 2012).

Annual mean streamflow during $1951-56$ and 2011 is shown in figure 6 for 19 unregulated USGS streamflow-gaging stations (fig. 1, table 2). Also, the mean streamflow for the period of record is shown for each station for reference. For most of these stations, annual mean streamflow during these drought years was well below the mean for the period of record. One exception is the Palo Duro gage in the northern part of the Texas Panhandle (fig. 1). The annual mean streamflow depicted for the Palo Duro gage (07233500, fig. 6) is consistent with the finding reported by Nace and Pluhowski (1965) that as early as 1953, streamflow in the Texas Panhandle region returned to normal. The annual mean streamflow for the Palo Duro gage was 0.0 cubic feet per second ( $\mathrm{ft}^{3} / \mathrm{s}$ ) (zero flow) during 2011, and the daily mean streamflow for each day in 2011 also was zero flow. Asquith and others (2007) showed an increasing occurrence of zero flow for the Palo Duro gage (07233500) for parts of each year during 1945-2003, but prior to 2011, an entire year of zero flow had never previously been recorded. The mean annual streamflow for the Palo Duro gage during 2000-10 was $3.05 \mathrm{ft}^{3} / \mathrm{s}$. It is not known to what extent the diminishing streamflows on Palo Duro Creek are caused by local diversion for agriculture or by declining water levels in the High Plains aquifer. McGuire (2011) indicates that between about 1950 and 2007, water levels in the High Plains aquifer declined by 50 to 100 feet in the northern part of the Texas Panhandle near Palo Duro Creek.

Other USGS streamflow-gaging stations for which the annual mean streamflow was lower in 2011 than for any year during 1951-56 include 07343000 North Sulphur River near Cooper, Tex., 07346070 Little Cypress Creek near Jefferson, Tex., 08041500 Village Creek near Kountze, Tex., 08070000 East Fork San Jacinto River near Cleveland, Tex., 08070500 Caney Creek near Splendora, Tex., 08134000 North Concho River near Carlsbad, Tex., and 08205500 Frio River near Derby, Tex.; many of these stations are located in eastern Texas. Upstream from Derby, Tex., in the upper Frio River Basin, annual mean streamflows for USGS streamflow-gaging stations 08195000 Frio River at Concan, Tex., and 08198000 Sabinal River near Sabinal, Tex., were lower in 1956 than in 2011. Annual mean streamflows for stations in the Guadalupe River Basin (08167500 Guadalupe River near Spring Branch, Tex.) and Blanco River Basin (08171000 Blanco River at Wimberley, Tex.) also were lower in 1956 than in 2011.

Streamflow-duration curves showing the percentage of time that a given streamflow was equaled or exceeded during 1956 and 2011 at 19 unregulated USGS streamflow-gaging stations are shown in figure 7. Additionally, streamflow duration for the period of record is shown in figure 7 for reference. For sites that occasionally go to zero flow, curves were extended to approximate the location of $0.1 \mathrm{ft}^{3} / \mathrm{s}$, the minimum flow plotted for the logarithmic scale. At stations 07346070 Little Cypress Creek near Jefferson, Tex., 08041500 Village Creek near Kountze, Tex., 08070000 East Fork San Jacinto River near Cleveland, Tex., and 08070500 Caney Creek near Splendora, Tex., streamflows during 2011 were lower than for any year during 1951-56 for all computed exceedance percentages. For many of the streamflow-gaging stations, the 2011 streamflow-duration curves lack the typical upward bend near the 5- and 10-percent exceedance percentages found in years with near-normal amounts of precipitation; the patterns of the streamflow-duration curves in figure 7 are consistent with a lack of storm runoff during 2011. The right-hand side of the curves represents lower streamflows typically maintained by inflows of local nearsurface groundwater. 

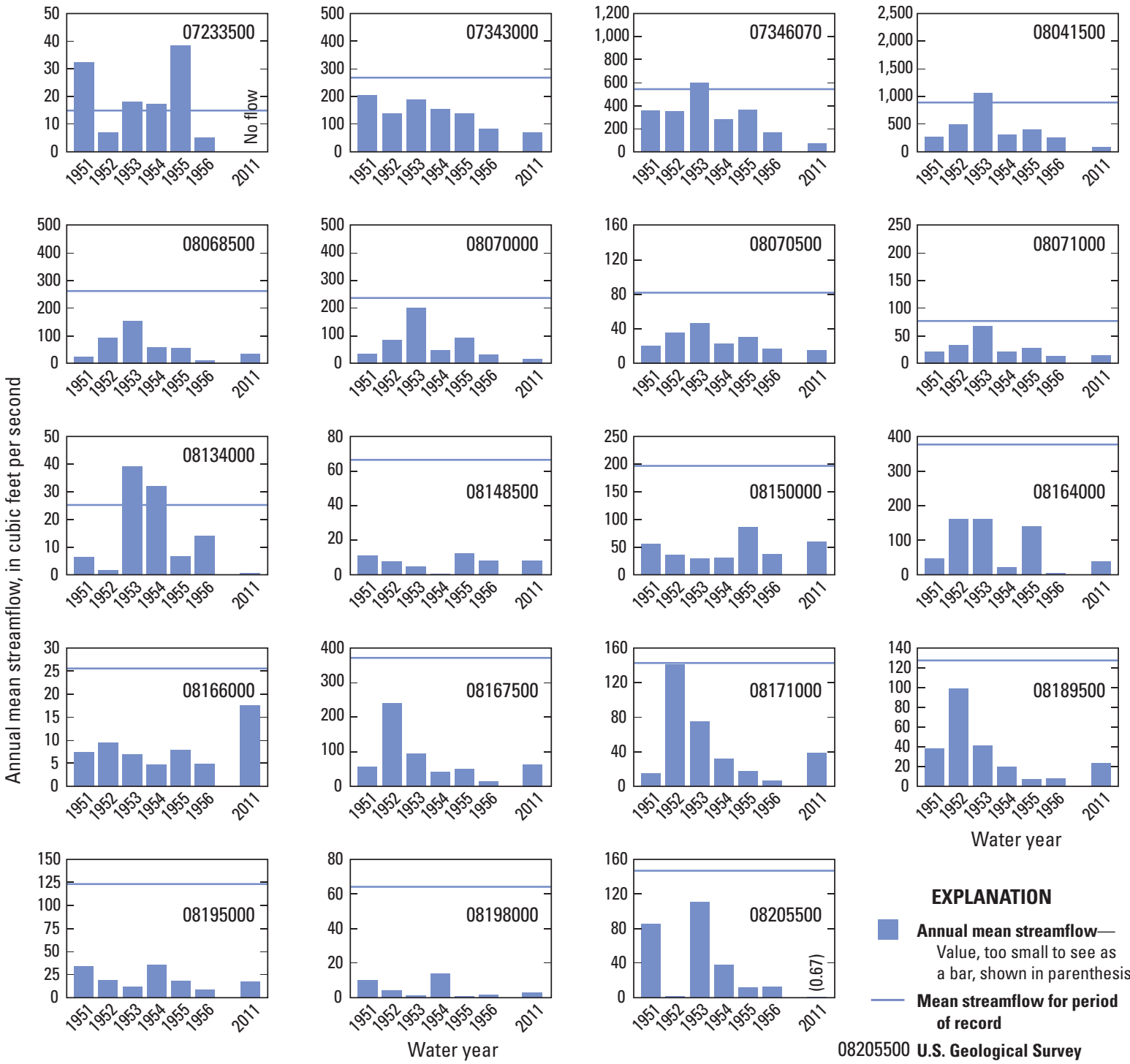

EXPLANATION

Annual mean streamflowValue, too small to see as a bar, shown in parenthesis

- Mean streamflow for period of record

08205500 U.S. Geological Survey streamflow-gaging station number-Table 2

Figure 6. Annual mean streamflow at selected unregulated U.S. Geological Survey streamflow-gaging stations in Texas during 1951-56 and 2011. 

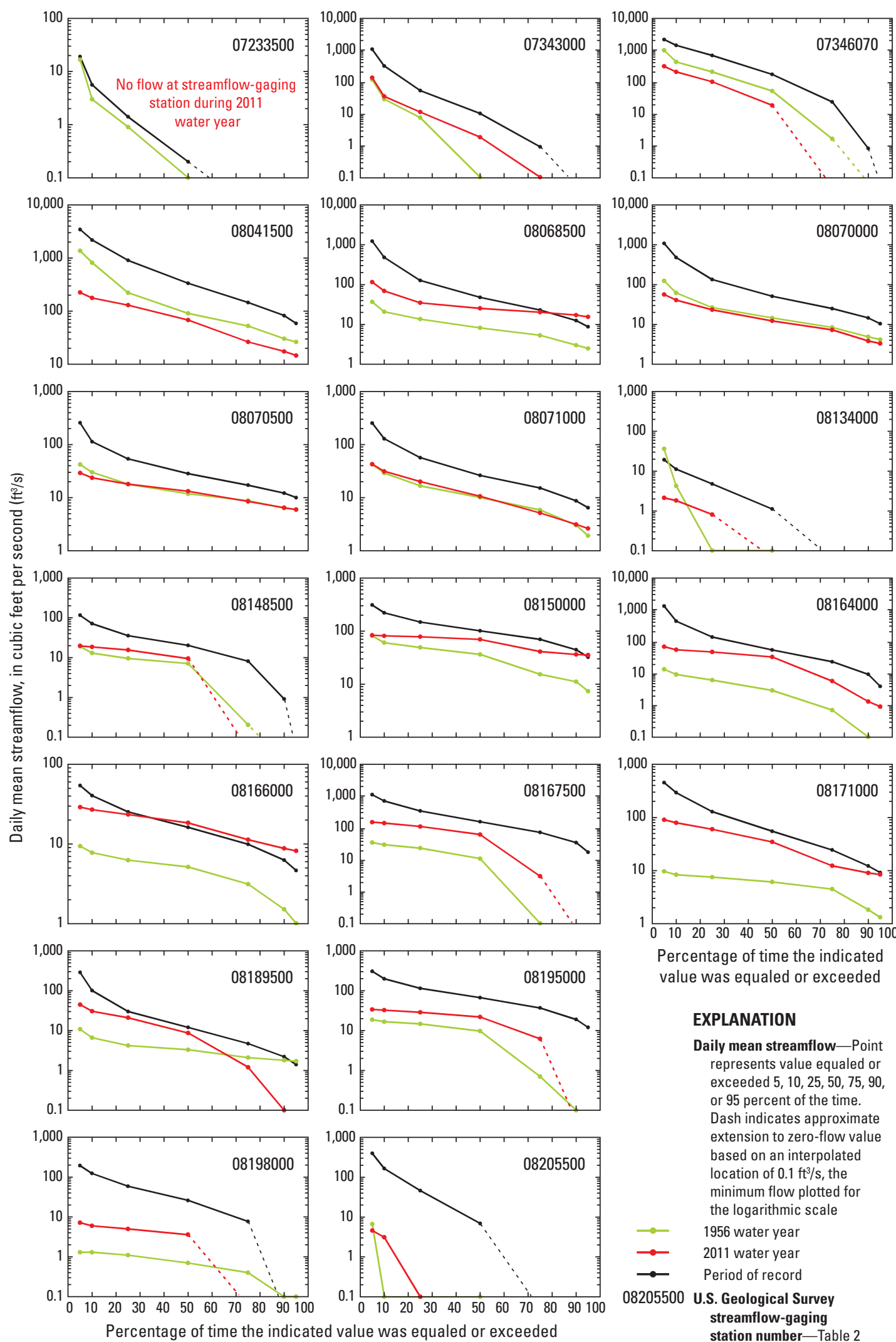
$\begin{array}{lllllllllll}0 & 10 & 20 & 30 & 40 & 50 & 60 & 70 & 80 & 90 & 100\end{array}$
Percentage of time the indicated value was equaled or exceeded

\section{EXPLANATION}

Daily mean streamflow-Point represents value equaled or exceeded $5,10,25,50,75,90$, or 95 percent of the time. Dash indicates approximate extension to zero-flow value based on an interpolated location of $0.1 \mathrm{ft}^{3} / \mathrm{s}$, the minimum flow plotted for the logarithmic scale 1956 water year 2011 water year Period of record

08205500 U.S. Geological Survey streamflow-gaging station number-Table 2

Figure 7. Streamflow duration for selected unregulated U.S. Geological Survey streamflow-gaging stations in Texas for 1956, 2011, and the period of record. 
Comparing the low flows of the 1951-56 and 2011 droughts from a historical perspective by considering data from the periods of record at individual streamflow-gaging stations is informative. For example, streamflows at station 07233500 Palo Duro Creek near Spearman, Tex., were frequently higher during $1951-55$ than for the period of record (fig. 6). Low flows at station 07346070 Little Cypress Creek near Jefferson, Tex., during 1953 were higher than for the period of record. At station 08166000 Johnson Creek near Ingram, Tex., a lack of storm runoff during 2011 is apparent, but for median and lower streamflows, streamflows in 2011 were greater than those for the period of record (fig. 7). Streamflows exceeded 90 or 95 percent of the time were lower for water year 1956 than for water year 2011 at stations 08068500 Spring Creek near Spring, Tex., 08071000 Peach Creek at Splendora, Tex., 8150000 Llano River near Junction, Tex., 08164000 Lavaca River near Edna, Tex., 08166000 Johnson Creek near Ingram, Tex., 08167500 Guadalupe River near Spring Branch, Tex., and 08171000 Blanco River at Wimberley, Tex. (fig. 7). For most of these stations, the minimum of the low streamflows during 1951-56 occurred in 1956 (fig. 6).

The USGS WaterWatch Web page (U.S. Geological Survey, 2012b) displays current and recent streamflow conditions with respect to daily streamflow duration. The effects of the 2011 drought on streamflow for 19 unregulated USGS streamflow-gaging stations (table 2) are shown in figures 8-26. Parts of the 2010 and 2012 water years are included for comparison to 2011. Station 07233500 Palo Duro Creek near Spearman, Tex., was dry throughout 2011, but recorded storm runoff during 2010 and 2012 (fig. 8). Streamflow at station 07343000 North Sulphur River near Cooper, Tex., was below normal (for this section of this report, normal indicates daily streamflow between the 25th and 75th percentile of recorded streamflows) during parts of March and April 2011, and during July through September 2011 (fig. 9). Streamflow at station 07346070 Little Cypress Creek near Jefferson, Tex., was well below normal from February through September 2011 (fig. 10). During March to September 2011, record daily lows were measured at USGS streamflow-gaging station 08041500 Village Creek near Kountze, Tex., which has more than 70 years of record (fig. 11), and station 08070000 East Fork San Jacinto River near Cleveland, Tex., was at or near record daily lows during March to September 2011 (fig. 13).

Many USGS streamflow-gaging stations in Texas started the 2011 water year with normal streamflow but by the end of the 2011 water year were flowing at near-record lows. Streamflows at USGS streamflow-gaging station 08068500 Spring Creek near Spring, Tex., were below normal during February through June 2011, but normal during July through September 2011 (fig. 12). Stations 08070500 Caney Creek near Splendora, Tex., and 08071000 Peach Creek near Splendora, Tex., (figs. 14 and $\underline{15}$, respectively) were at or near record daily lows during May to September 2011. Station 08134000 North Concho River near Carlsbad, Tex., frequently goes dry during summer months; streamflows on the North Concho River were at or below normal during all of 2011, except for a brief period of storm runoff in August 2011 (fig. 16). Streamflows at stations 08148500 North Llano River near Junction, Tex., and 08150000 Llano River near Junction, Tex., (figs. 17 and $\underline{18}$, respectively) were near normal during October 2010 to February 2011, but below normal during March to September 2011. Streamflows at station 08166000 Johnson Creek near Ingram, Tex., were near normal during the 2011 water year (fig. 20). Stations 08164000 Lavaca River near Edna, Tex., (fig. 19) and 08189500 Mission River at Refugio, Tex. (fig. 23), recorded storm runoff during January 2011 but by September 2011 were flowing at near-record lows. Streamflows at stations 08167500 Guadalupe River near Spring Branch, Tex., and 08171000 Blanco River near Wimberley, Tex., (figs. 21 and 22, respectively) were at or near normal from October 2010 through February 2011, but then remained below normal through September 2011. Streamflows at stations 08195000 Frio River at Concan, Tex., and 08198000 Sabinal River near Sabinal, Tex., (figs. 24 and $\underline{25}$, respectively) fell below normal in October 2010, and remained there through September 2011. Station 08205500 Frio River near Derby, Tex., which typically records zero flow about 30 percent of the time, recorded zero flow for 9 months during the 2011 water year (fig. 26). 


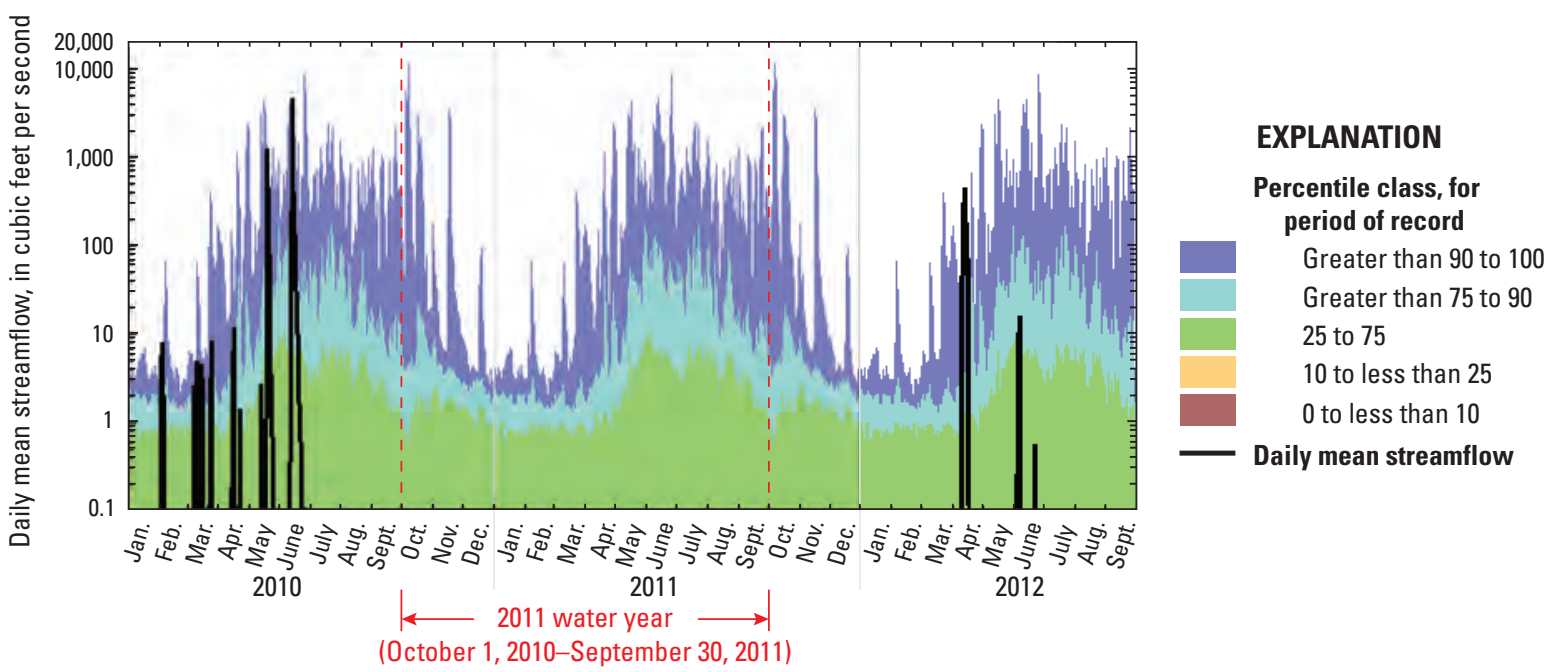

Figure 8. Streamflow duration and daily mean streamflow during January 2010 to September 2012 for U.S. Geological Survey streamflow-gaging station 07233500 Palo Duro Creek near Spearman, Texas (modified from U.S. Geological Survey, 2012b).

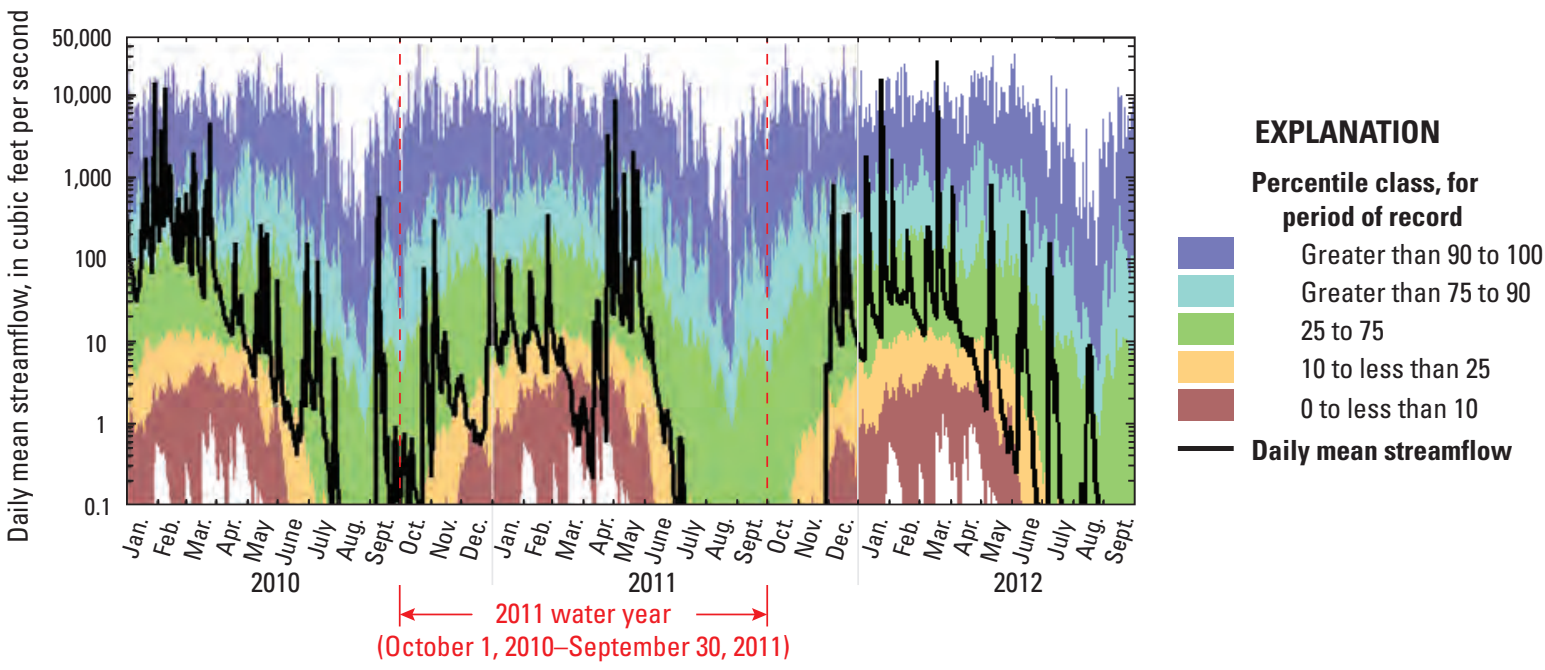

Figure 9. Streamflow duration and daily mean streamflow during January 2010 to September 2012 for U.S. Geological Survey streamflow-gaging station 07343000 North Sulphur River near Cooper, Texas (modified from U.S. Geological Survey, 2012b). 

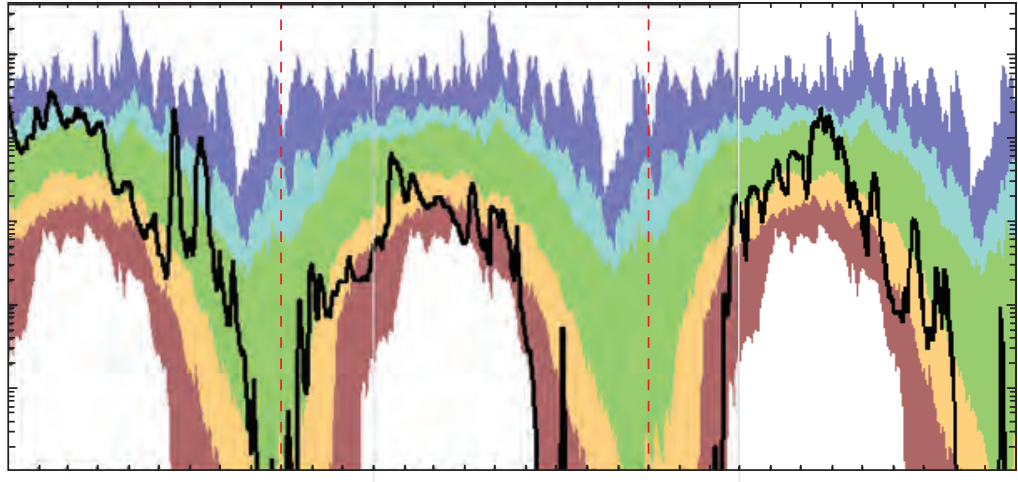

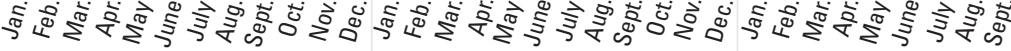
2010

\section{1}

2011 water year

(October 1, 2010-September 30, 2011)

\section{EXPLANATION}

Percentile class, for period of record

Greater than 90 to 100 Greater than 75 to 90

25 to 75

10 to less than 25

0 to less than 10

Daily mean streamflow

Figure 10. Streamflow duration and daily mean streamflow during January 2010 to September 2012 for U.S. Geological Survey streamflow-gaging station 07346070 Little Cypress Creek near Jefferson, Texas (modified from U.S. Geological Survey, 2012b).

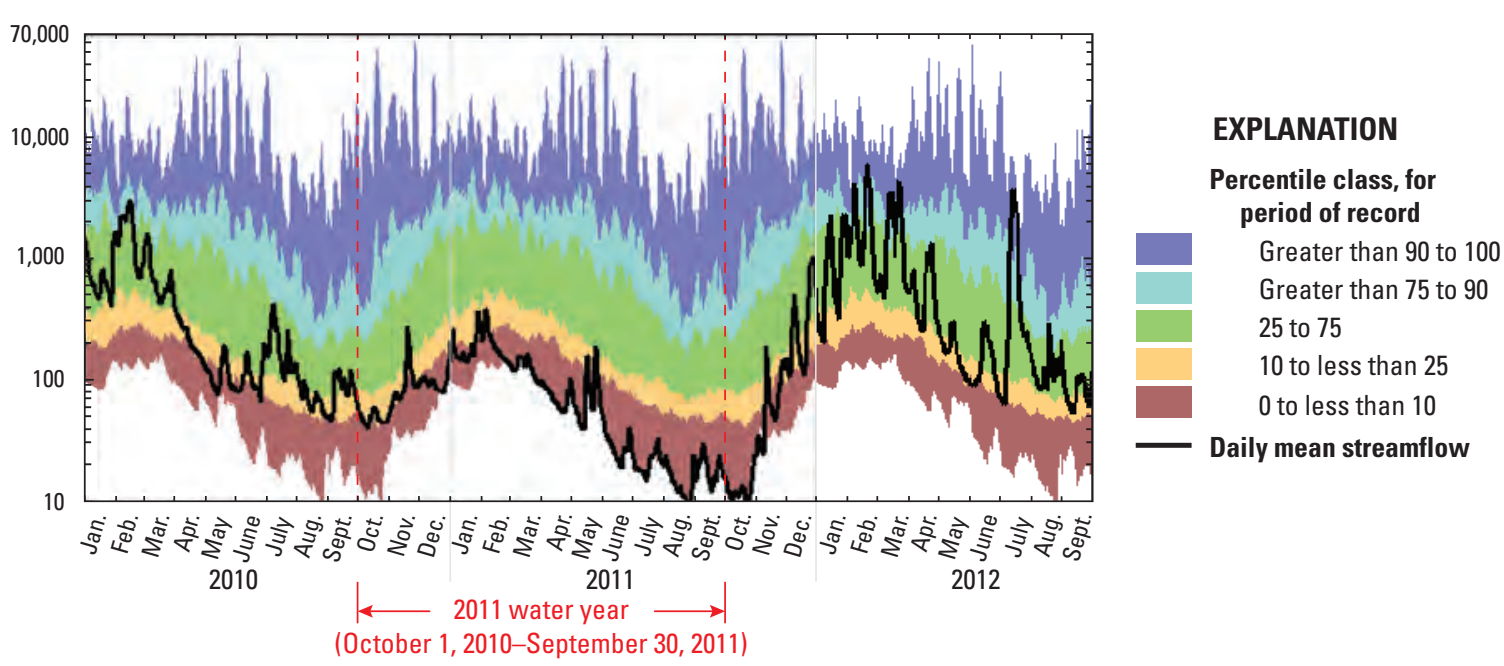

Figure 11. Streamflow duration and daily mean streamflow during January 2010 to September 2012 for U.S. Geological Survey streamflow-gaging station 08041500 Village Creek near Kountze, Texas (modified from U.S. Geological Survey, 2012b). 


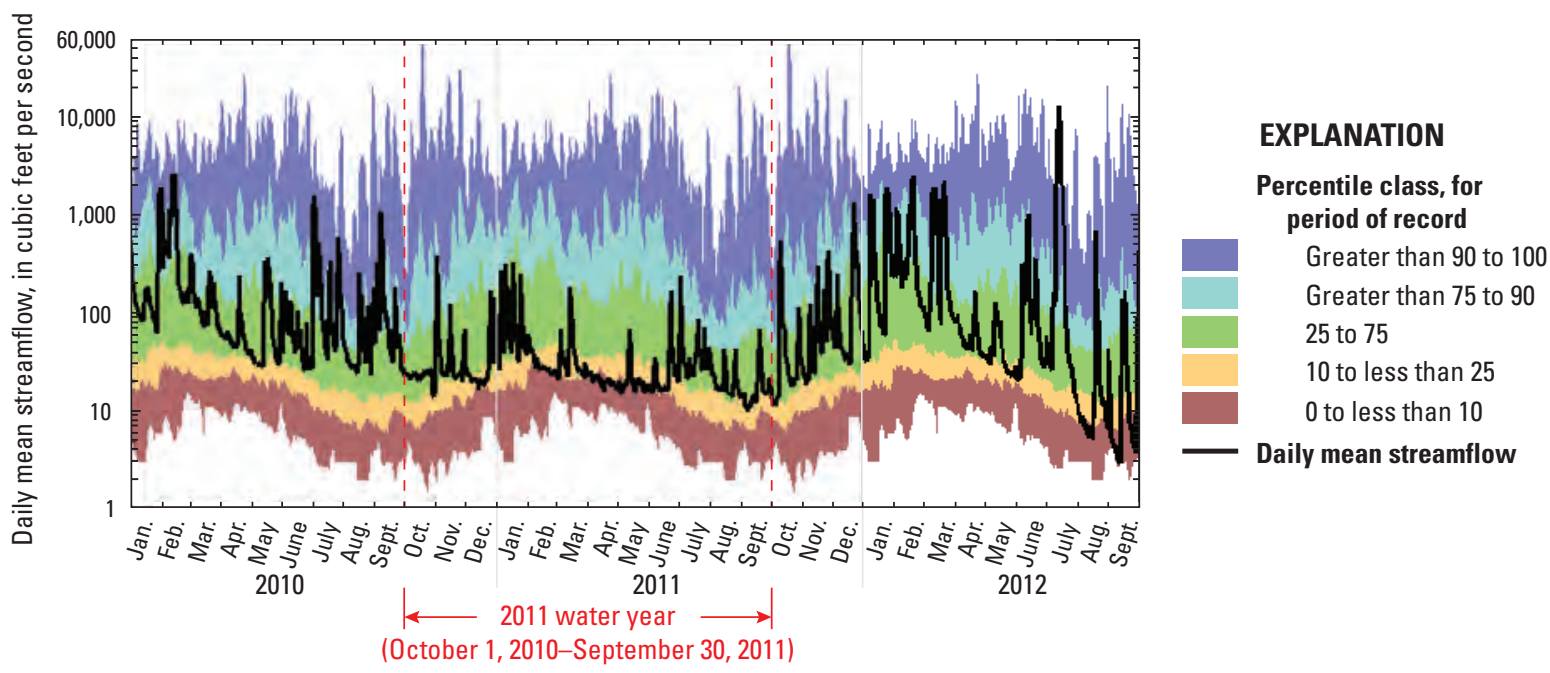

Figure 12. Streamflow duration and daily mean streamflow during January 2010 to September 2012 for U.S. Geological Survey streamflow-gaging station 08068500 Spring Creek near Spring, Texas (modified from U.S. Geological Survey, 2012b).

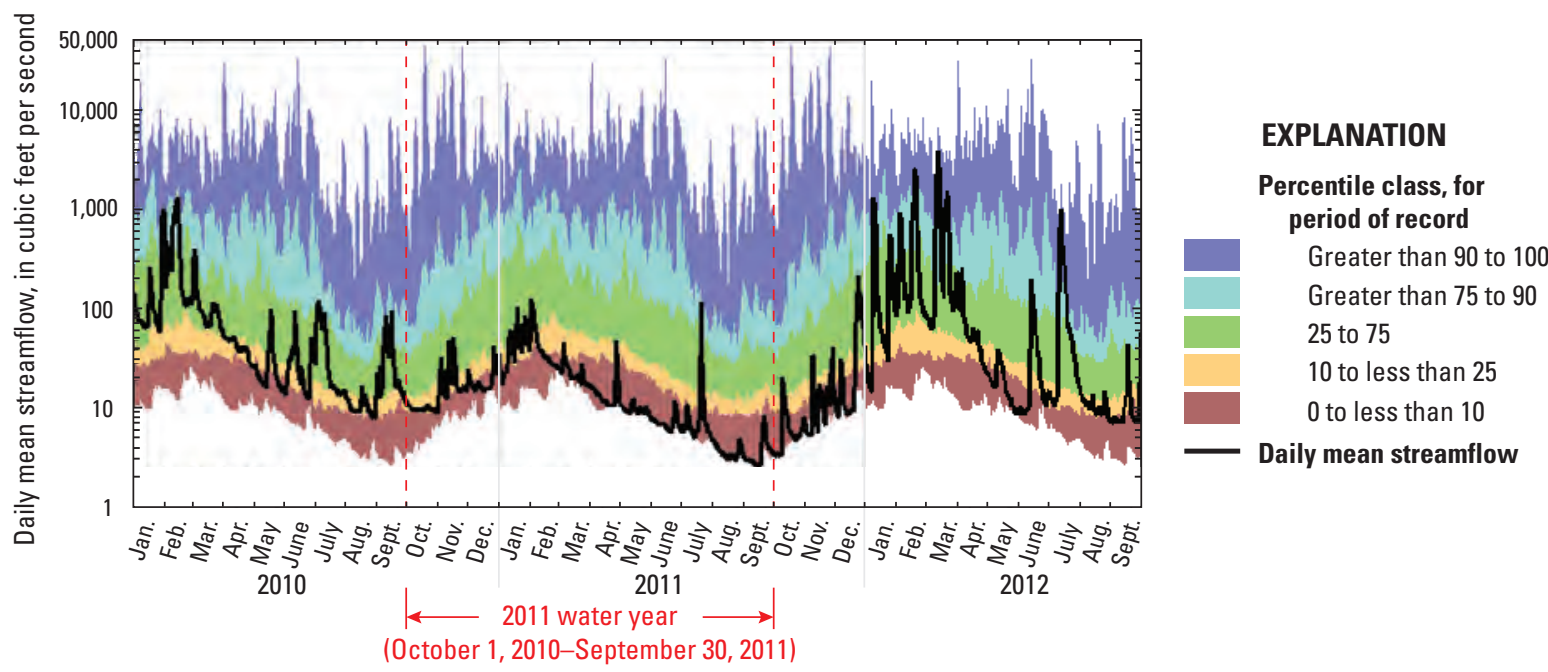

Figure 13. Streamflow duration and daily mean streamflow during January 2010 to September 2012 for U.S. Geological Survey streamflow-gaging station 08070000 East Fork San Jacinto River near Cleveland, Texas (modified from U.S. Geological Survey, 2012b). 


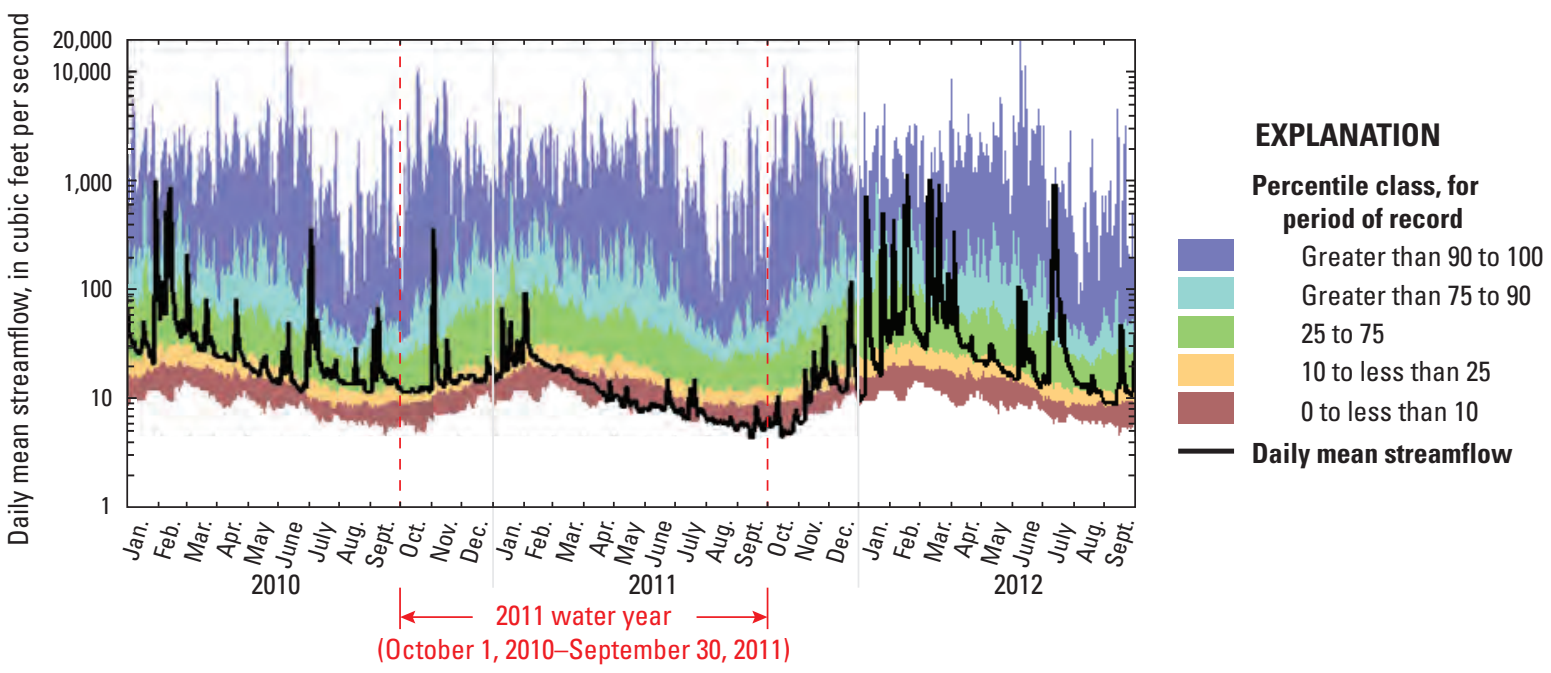

Figure 14. Streamflow duration and daily mean streamflow during January 2010 to September 2012 for U.S. Geological Survey streamflow-gaging station 08070500 Caney Creek near Splendora, Texas (modified from U.S. Geological Survey, 2012b).

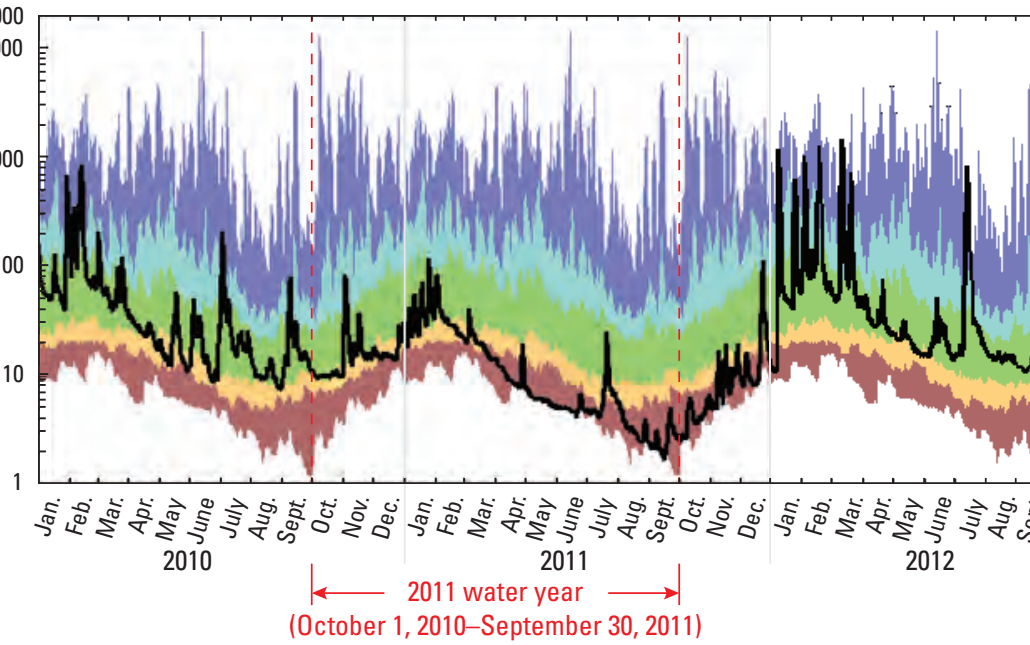

\section{EXPLANATION}

Percentile class, for period of record

Greater than 90 to 100

Greater than 75 to 90

25 to 75

10 to less than 25

0 to less than 10

\section{Daily mean streamflow}

Figure 15. Streamflow duration and daily mean streamflow during January 2010 to September 2012 for U.S. Geological Survey streamflow-gaging station 08071000 Peach Creek at Splendora, Texas (modified from U.S. Geological Survey, 2012b). 


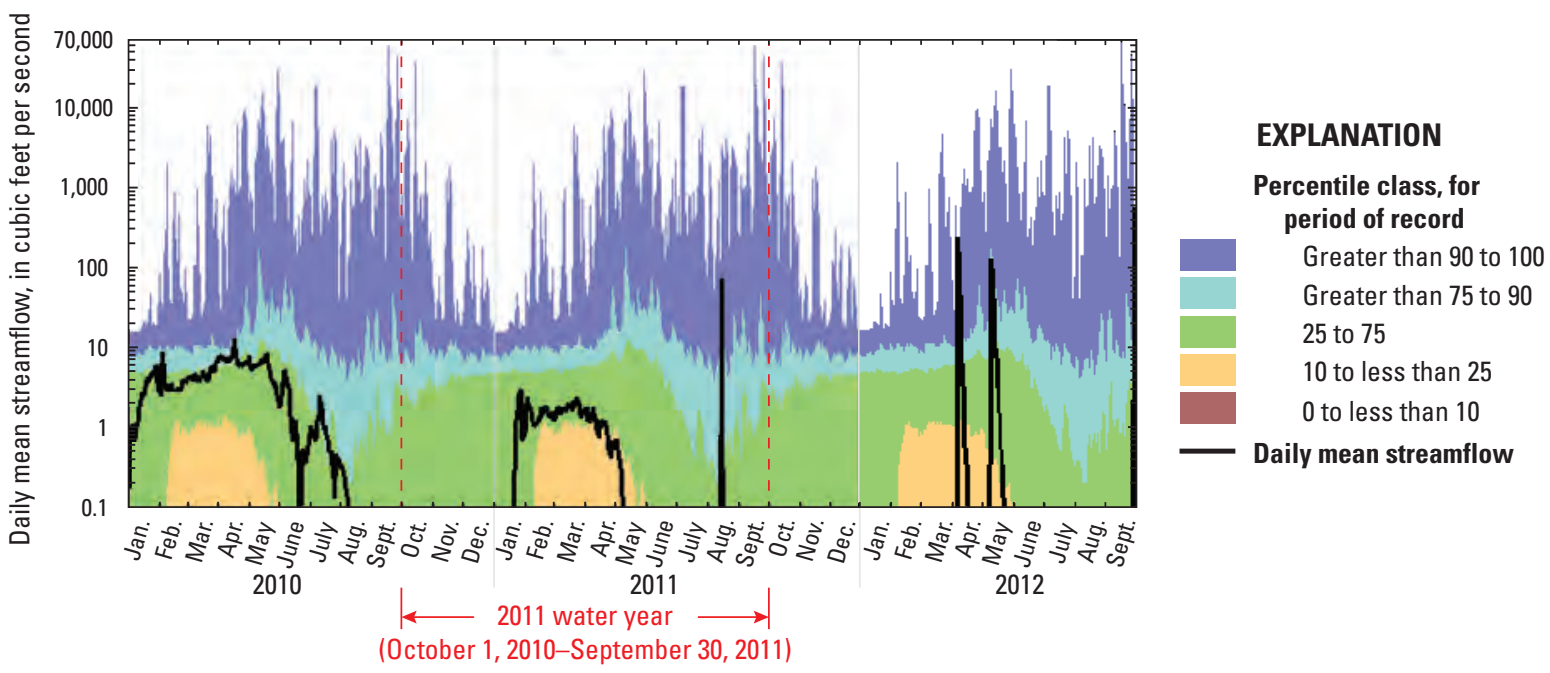

Figure 16. Streamflow duration and daily mean streamflow during January 2010 to September 2012 for U.S. Geological Survey streamflow-gaging station 08134000 North Concho River near Carlsbad, Texas (modified from U.S. Geological Survey, 2012b).

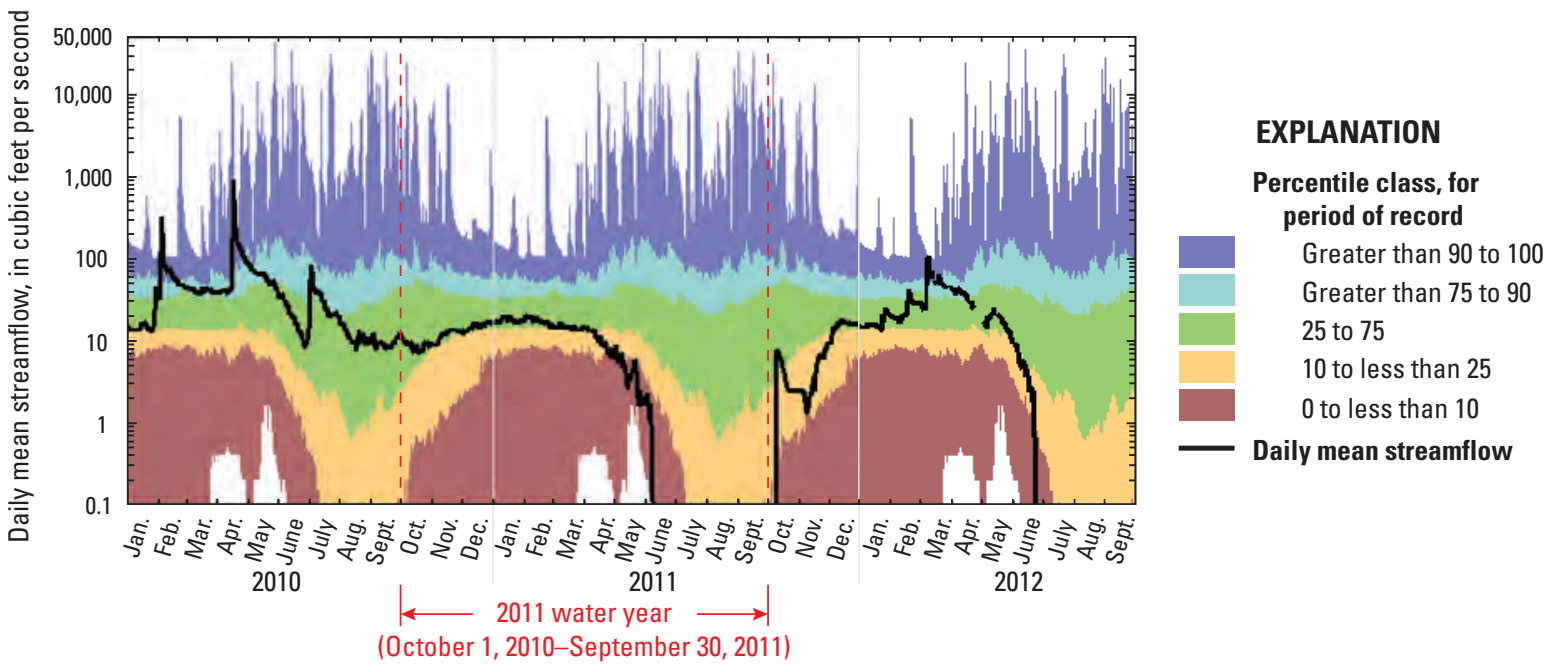

Figure 17. Streamflow duration and daily mean streamflow during January 2010 to September 2012 for U.S. Geological Survey streamflow-gaging station 08148500 North Llano River near Junction, Texas (modified from U.S. Geological Survey, 2012b). 


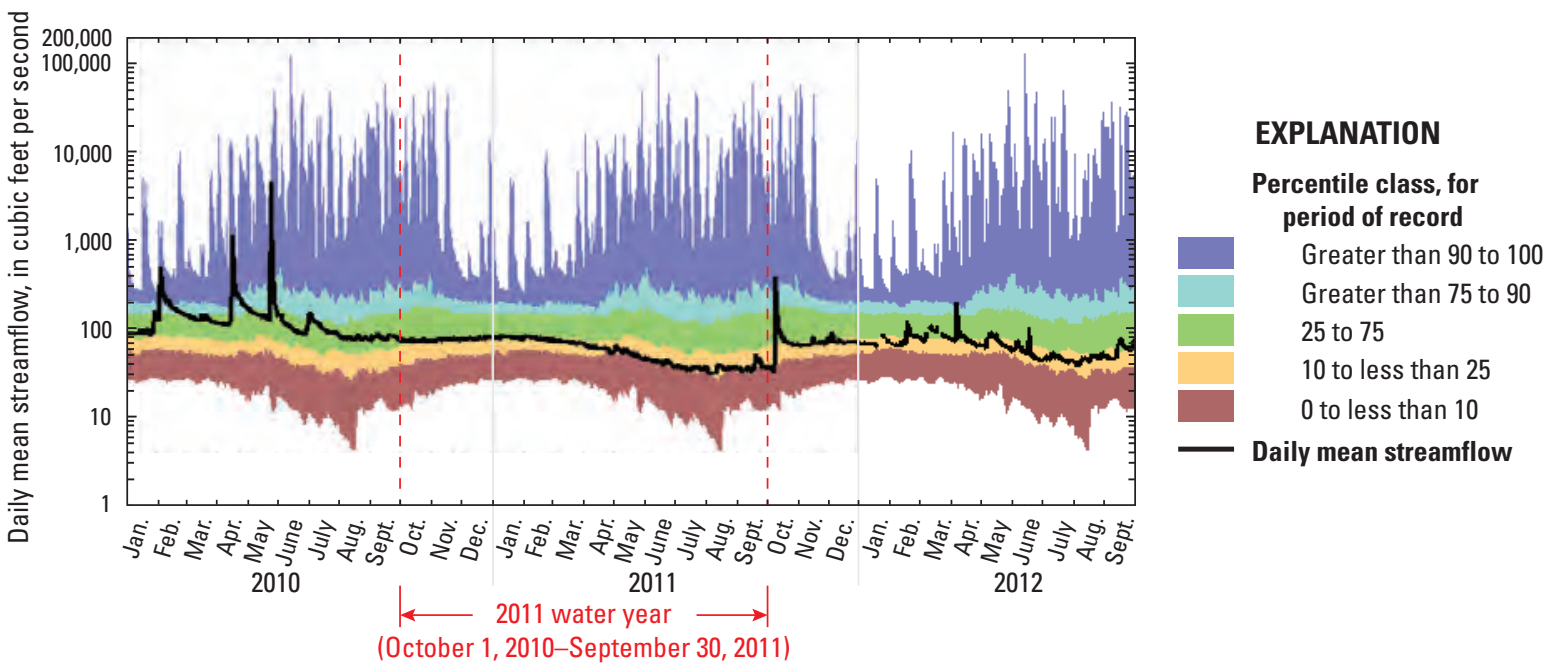

Figure 18. Streamflow duration and daily mean streamflow during January 2010 to September 2012 for U.S. Geological Survey streamflow-gaging station 08150000 Llano River near Junction, Texas (modified from U.S. Geological Survey, 2012b).

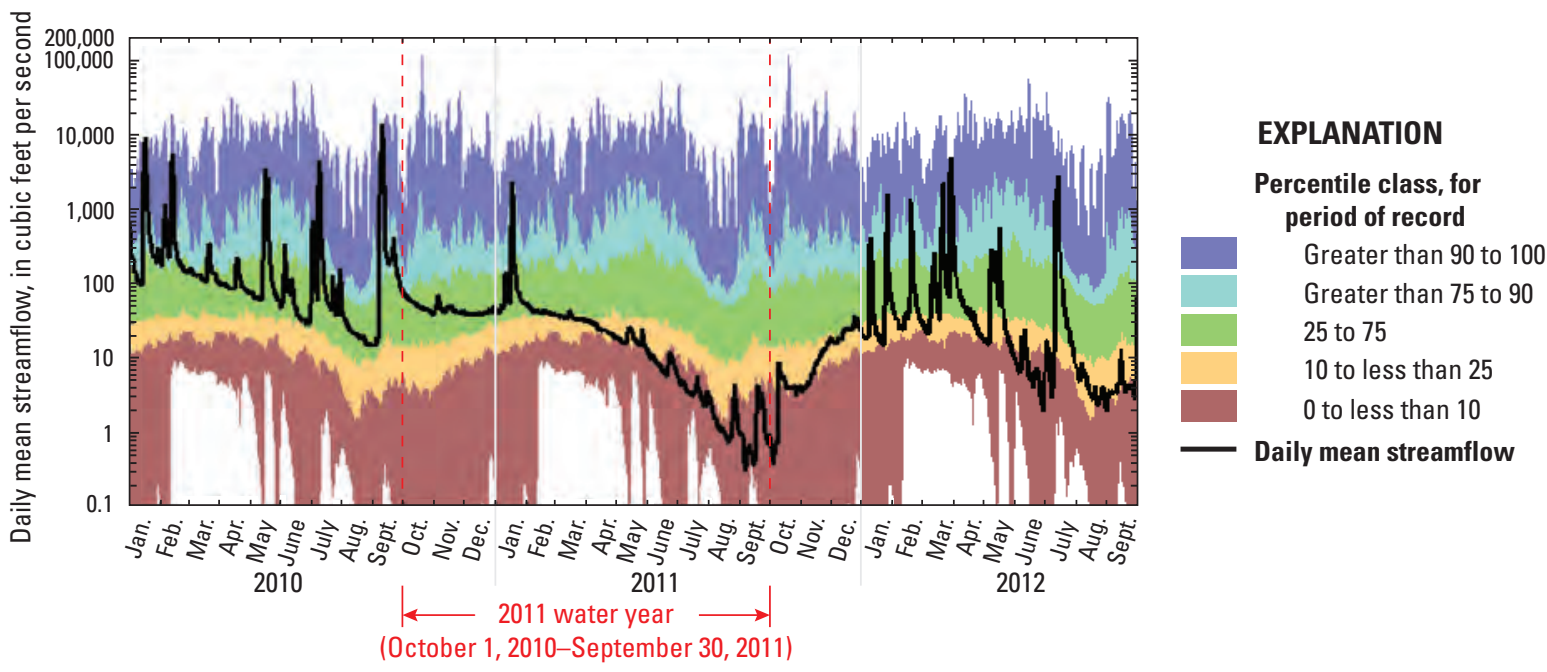

Figure 19. Streamflow duration and daily mean streamflow during January 2010 to September 2012 for U.S. Geological Survey streamflow-gaging station 08164000 Lavaca River near Edna, Texas (modified from U.S. Geological Survey, 2012b). 


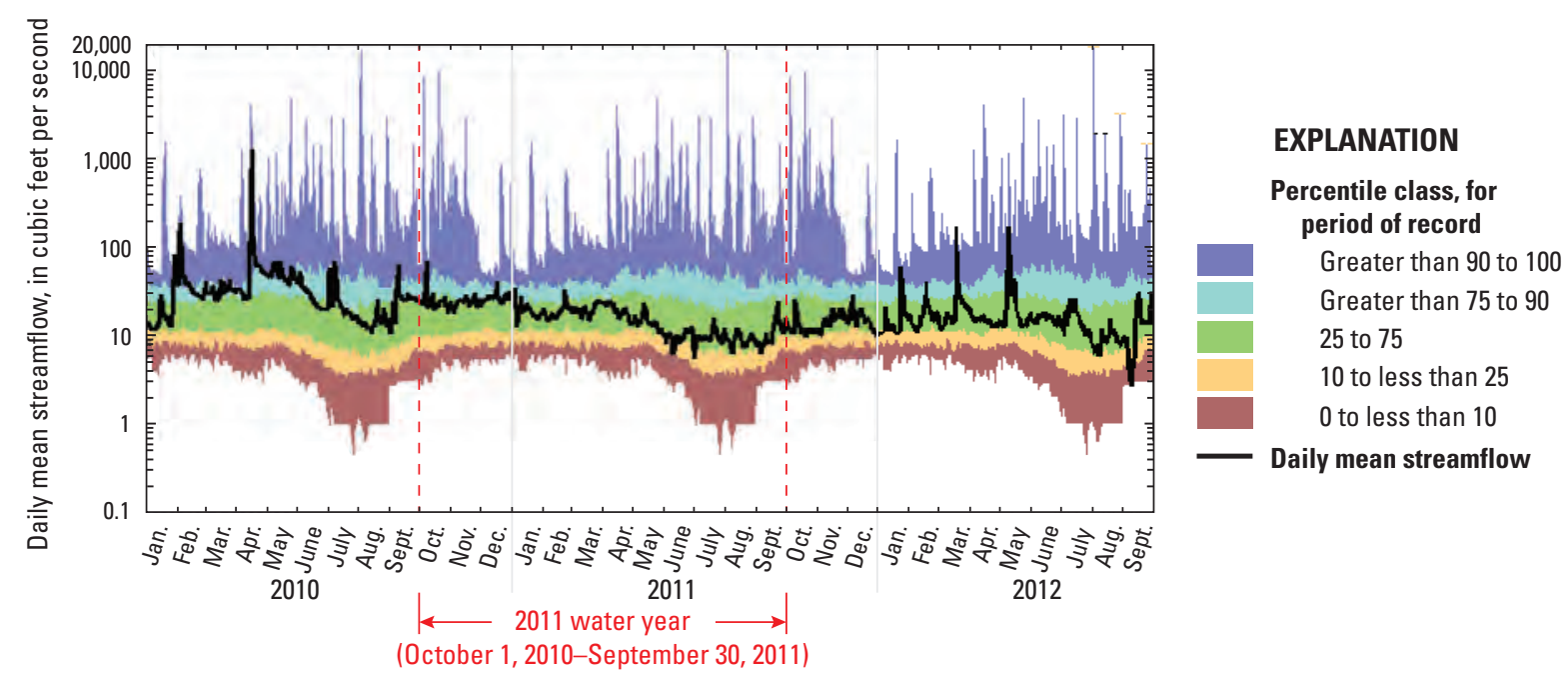

Figure 20. Streamflow duration and daily mean streamflow during January 2010 to September 2012 for U.S. Geological Survey streamflow-gaging station 08166000 Johnson Creek near Ingram, Texas (modified from U.S. Geological Survey, 2012b).
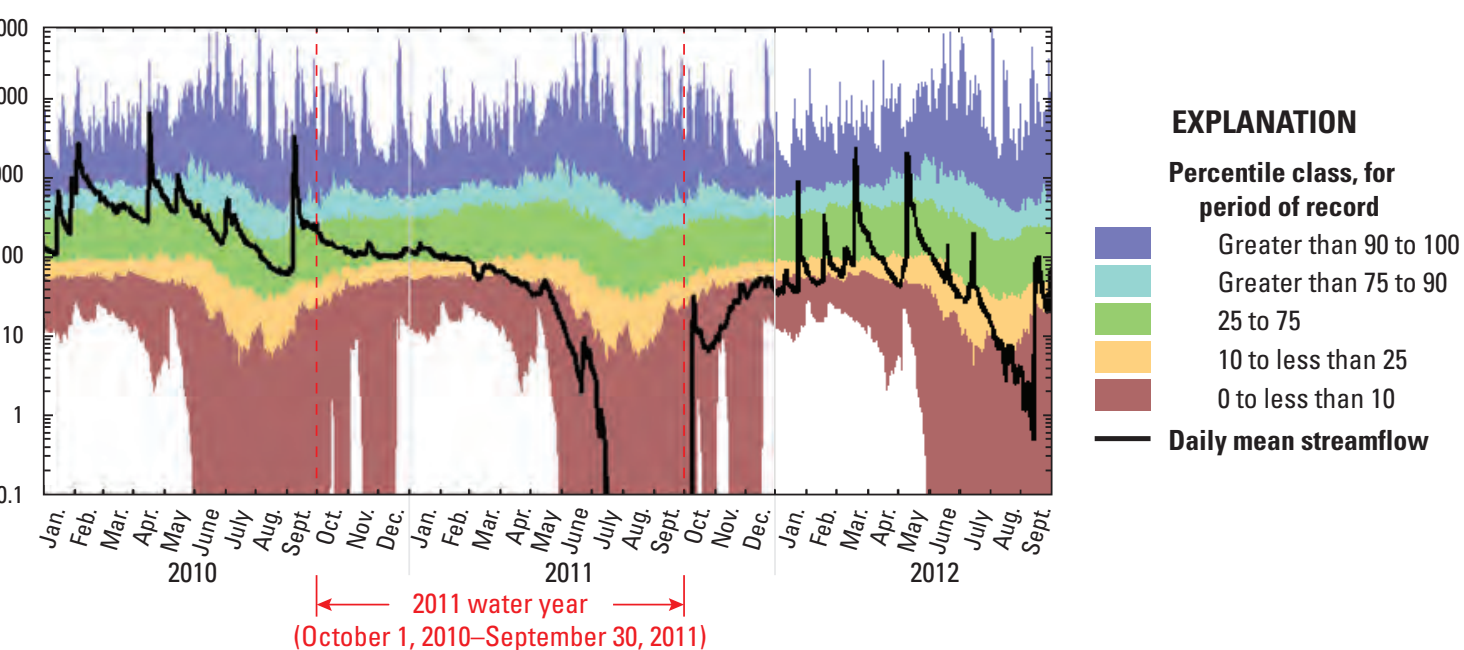

Figure 21. Streamflow duration and daily mean streamflow during January 2010 to September 2012 for U.S. Geological Survey streamflow-gaging station 08167500 Guadalupe River near Spring Branch, Texas (modified from U.S. Geological Survey, 2012b). 


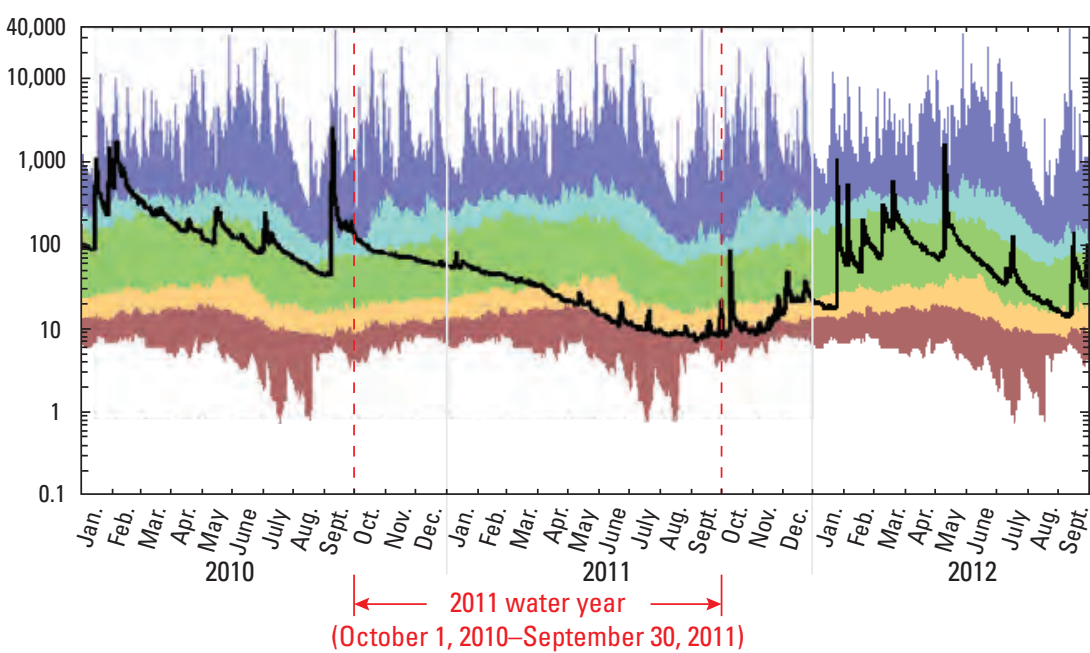

\section{EXPLANATION}

Percentile class, for period of record

Greater than 90 to 100 Greater than 75 to 90

25 to 75

10 to less than 25

0 to less than 10

Daily mean streamflow

Figure 22. Streamflow duration and daily mean streamflow during January 2010 to September 2012 for U.S. Geological Survey streamflow-gaging station 08171000 Blanco River at Wimberley, Texas (modified from U.S. Geological Survey, 2012b).

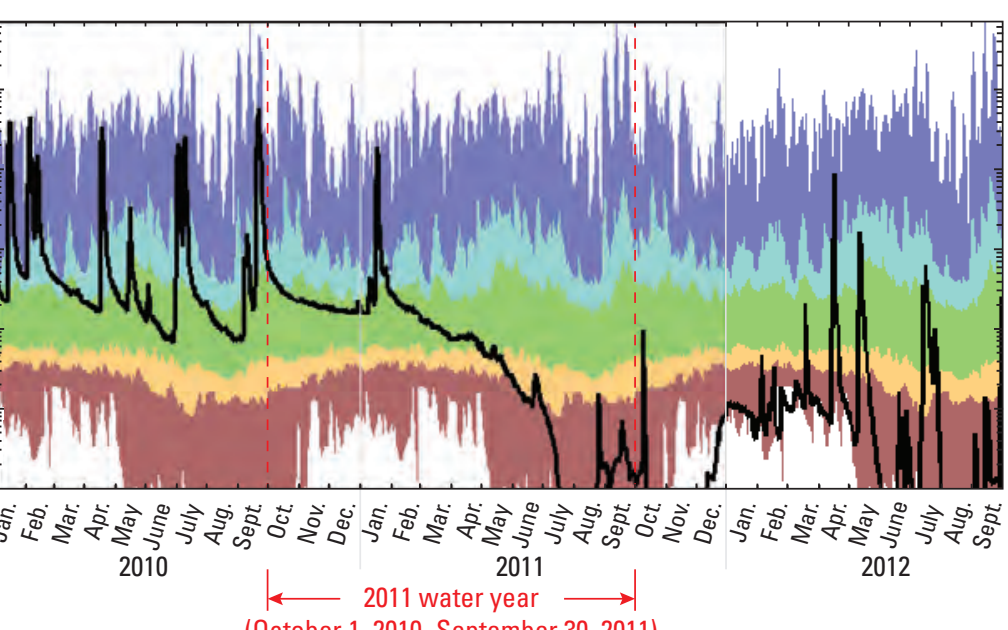

\section{EXPLANATION \\ Percentile class, for period of record \\ Greater than 90 to 100 \\ Greater than 75 to 90 \\ 25 to 75 \\ 10 to less than 25 \\ 0 to less than 10}

Daily mean streamflow

(October 1, 2010-September 30, 2011)

Figure 23. Streamflow duration and daily mean streamflow during January 2010 to September 2012 for U.S. Geological Survey streamflow-gaging station 08189500 Mission River at Refugio, Texas (modified from U.S. Geological Survey, 2012b). 


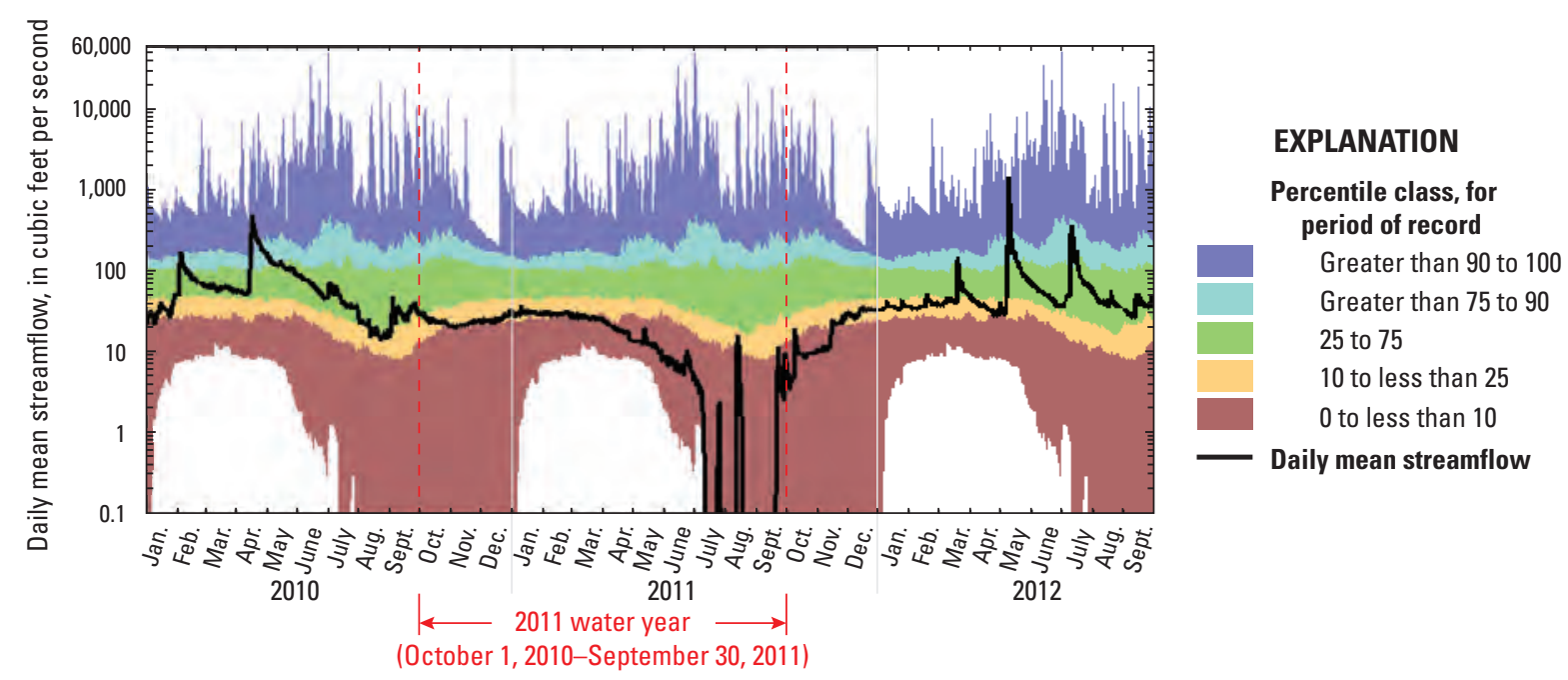

Figure 24. Streamflow duration and daily mean streamflow during January 2010 to September 2012 for U.S. Geological Survey streamflow-gaging station 08195000 Frio River at Concan, Texas (modified from U.S. Geological Survey, 2012b).

0.1

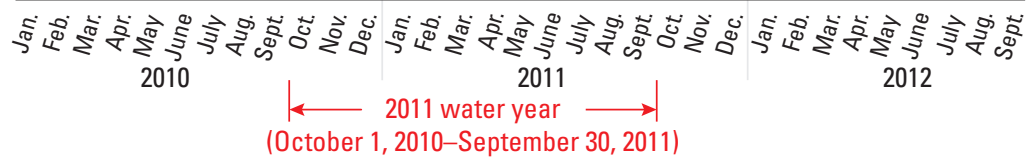

\section{EXPLANATION}

Percentile class, for period of record Greater than 90 to 100 Greater than 75 to 90 25 to 75 10 to less than 25 0 to less than 10 Daily mean streamflow

Figure 25. Streamflow duration and daily mean streamflow during January 2010 to September 2012 for U.S. Geological Survey streamflow-gaging station 08198000 Sabinal River near Sabinal, Texas (modified from U.S. Geological Survey, 2012b). 


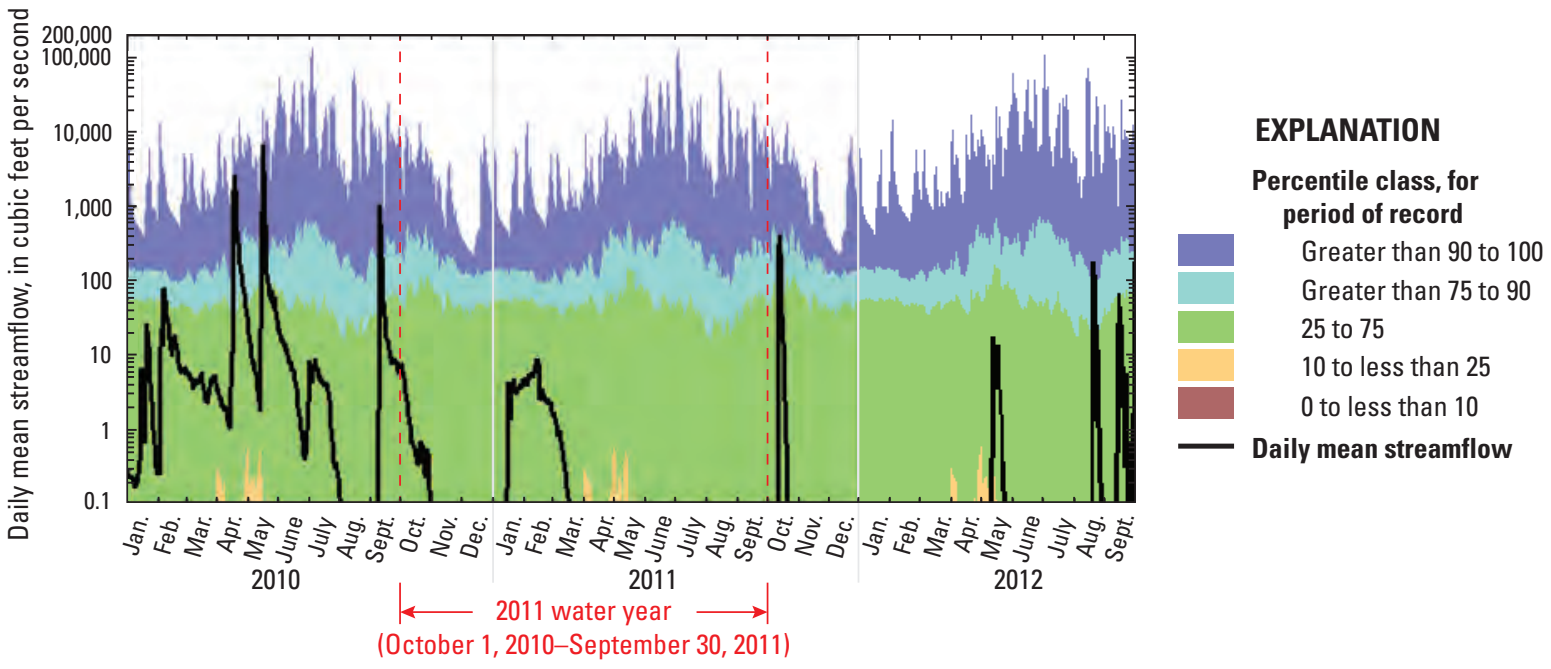

Figue 26. Streamflow duration and daily mean streamflow during January 2010 to September 2012 for U.S. Geological Survey streamflow-gaging station 08205500 Frio River near Derby, Texas (modified from U.S. Geological Survey, 2012b).

\section{Summary}

The intense drought that occurred throughout Texas during 2011 resulted in large precipitation deficits throughout the State, large drought severity indexes (Drought Monitor and Palmer Drought Severity Indexes), and substantial declines in streamflow. A record low statewide average annual precipitation of 11.27 inches for the period 1895-2011 was recorded during the 2011 water year; the prior record low statewide average precipitation was 13.91 inches during the 1956 water year. The statewide average annual precipitation during each of the years 1951-56 was less than the normal statewide average annual precipitation of 27.95 inches. The historical drought of 1951-56 has long been used by water-resource managers, engineers, and scientists as a point of reference for water-supply planning. A comparison of the 2011 drought to the drought of 1951-56 provides an additional reference for water-supply planning. In 2012, the U.S. Geological Survey (USGS), in cooperation with the Texas Water Development Board, assessed the effects of the 1951-56 and 2011 droughts from a hydrologic perspective. Between August 1951 and November 1952, 14 of 16 monthly Palmer Drought Severity Index (PDSI) values indicated extreme drought. The 2011 water year began October 1, 2010, with parts of Texas being abnormally dry, but none of Texas was classified as in drought, according to data from the Drought Monitor. By April 2011, nearly all of the State was experiencing severe to extreme drought, and by the end of July 2011, more than 75 percent of the State was experiencing exceptional drought. Statewide PDSI values also indicated extreme drought during the entire 1955 and 1956 water years. The lowest statewide PDSI during the period 1951-56 was -7.8 , occurring September 1956. The statewide monthly PDSI declined to -7.93 during September 2011 and was larger in magnitude (larger negative value) than the monthly PDSI for any drought-affected month during the 1950s.

Annual mean streamflow during 1951-56 and 2011 was assessed for 19 unregulated USGS streamflow-gaging stations. For most of these sites, annual mean streamflows were well below the mean for the period of record. At eight of these streamflow-gaging stations, the annual mean streamflow was lower in 2011 than for any year during 1951-56; many of these stations are located in eastern Texas. Annual mean streamflow for streamflow-gaging stations in the Guadalupe, Blanco, and upper Frio River Basins were lower in 1956 than in 2011.

Streamflow-duration curves for 1956, 2011, and the period of record for the 19 unregulated USGS streamflowgaging stations show streamflows exceeded 90 to 95 percent of days were lower during 2011 than during 1956 at seven of the streamflow-gaging stations. The streamflow-duration curves for many streamflow-gaging stations indicate a lack of (or diminished) storm runoff during 2011. During March to September 2011, record daily lows were measured at USGS streamflow-gaging station 08041500 Village Creek near Kountze, Tex., which has more than 70 years of record. Many other USGS streamflow-gaging stations in Texas started the 2011 water year (October 1, 2010) with normal streamflow but by the end of the 2011 water year (September 2011) were flowing at near-record lows. 


\section{References}

Asquith, W.H., 2001, Effects of regulation on L-moments of annual peak streamflow in Texas: U.S. Geological Survey Water-Resources Investigations Report 01-4243, 66 p.

Asquith, W.H., and Heitmuller, F.T., 2008, Summary of annual mean and annual harmonic mean statistics of daily mean streamflow for 620 U.S. Geological Survey streamflowgaging stations in Texas through water year 2007: U.S. Geological Survey Data Series 372, 1,259 p.

Asquith, W.H., and Roussel, M.C., 2007, An initialabstraction, constant-loss model for unit-hydrograph modeling for applicable watersheds in Texas: U.S. Geological Survey Scientific Investigations Report 20075243, $82 \mathrm{p}$.

Asquith, W.H., Vrabel, Joseph, and Roussel, M.C., 2007, Summary of percentages of zero daily mean streamflow for 712 U.S. Geological Survey streamflow-gaging stations in Texas through 2003: U.S. Geological Survey Data Series $247,721 \mathrm{p}$.

Cleaveland, M.K., Votteler, T.H., Stahle, D.K., Casteel, R.C., and Banner, J.L., 2011, Extended chronology of drought in south central, southeastern and west Texas: Texas Water Journal, vol. 2, no. 1, accessed August 3, 2012, at https:// journals.tdl.org/twj/article/view/2049.

Dallas Morning News, 2011, Texas has hottest June-August on record in the U.S.: The Associated Press, September 8, 2011, accessed March 25, 2013, at http://www.dallasnews. com/news/state/headlines/20110908-texas-has-hottest-juneaugust-on-record-in-the-u.s..ece.

Jain, S.K., and Singh, V.P., 2005, Isohyetal method: Water Encyclopedia, v. 4, p. 290-292.

McGuire, V.L., 2011, Water-level changes in the High Plains aquifer, predevelopment to 2009, 2007-08, and 2008-09, and change in water in storage, predevelopment to 2009: U.S. Geological Survey Scientific Investigations Report 2011-5089, 13 p. (Also available at http://pubs.usgs.gov/ $\underline{\text { sir/2011/5089/.) }}$

Nace, R.L., and Pluhowski, E.J., 1965, Drought of the 1950's with special reference to the midcontinent: U.S. Geological Survey Water-Supply Paper 1804, 88 p.

National Weather Service, 2012, Advanced Hydrologic Prediction Service: accessed August 2012, at http://water. weather.gov/precip/.

Nielsen-Gammon, J.W., 2011, The 2011 Texas drought - A briefing packet for the Texas legislature: Office of the State Climatologist, College Station, Texas A\&M University, accessed August 26, 2012, at http://climatexas.tamu.edu/ files/2011 drought.pdf.
Palmer, W.C., 1965, Meteorological drought: U.S. Department of Commerce Weather Bureau Research Paper No. 45, 58 p.

Searcy, J.K., 1959, Flow-duration curves: U.S. Geological Survey Water-Supply Paper 1542-A, 33 p.

Texas A\&M University, 2011, Texas drought officially the worst ever: accessed August 2011, at http://tamunews.tamu. edu/texas-drought-officially-the-worst-ever/.

Texas Water Development Board, 2013, Water for Texas 2012 State Water Plan: Texas Water Development Board, accessed March 25, 2013, at http://www.twdb.state.tx.us/ publications/state_water_plan/2012/2012_SWP.pdf.

Thomas, H.E., and others, 1963, Drought in the Southwest, 1942-56; Effects of drought in central and south Texas: U.S. Geological Survey Professional Paper 372-C, 31 p.

University of Nebraska-Lincoln, 2012, The Drought Monitor, accessed July 2012, at http://droughtmonitor.unl.edu/.

U.S. Department of Agriculture, National Agriculture Statistics Service, 2013, Texas climate divisions map: Texas Field Office, U.S. Department of Agriculture, accessed January 24, 2013, at http://www.nass.usda.gov/Statistics by_State/Texas/Charts_\&_Maps/cwmap.htm.

U.S. Department of Commerce, National Climatic Data Center, 2012, Texas Precipitation, OctoberSeptember 1896-2012: Asheville, North Carolina, National Climatic Data Center, accessed October 2012, at http://www.ncdc.noaa.gov/temp-and-precip/timeseries/index.php?parameter $=$ pcp \&month $=9 \&$ year $=$ $\underline{2011 \& \text { filter }=12 \& \text { state }=41 \& \operatorname{div}=0}$.

U.S. Department of Commerce, Weather Bureau, 1957, Climatological data: Texas, annual summary 1956: v. LXI, no. $13,27 \mathrm{p}$.

U.S. Geological Survey, 2008, User's manual for the National Water Information System of the U.S. Geological Survey Automated Data Processing System (ADAPS): U.S. Geological Survey database, accessed October 11, 2012, at http://nwis.usgs.gov/nwisdocs4 8/adaps/adaps.book.html.

U.S. Geological Survey, 2012a, National Water Information System (NWISWeb): U.S. Geological Survey database, accessed August 2012, at http://waterdata.usgs.gov/tx/nwis/.

U.S. Geological Survey, 2012b, WaterWatch: U.S. Geological Survey Web site, accessed November 2012, at http:// waterwatch.usgs.gov/. 
Publishing support provided by Lafayette and Tacoma Publishing Service Centers

Information regarding water resources in Texas is available at http://tx.usgs.gov/ 

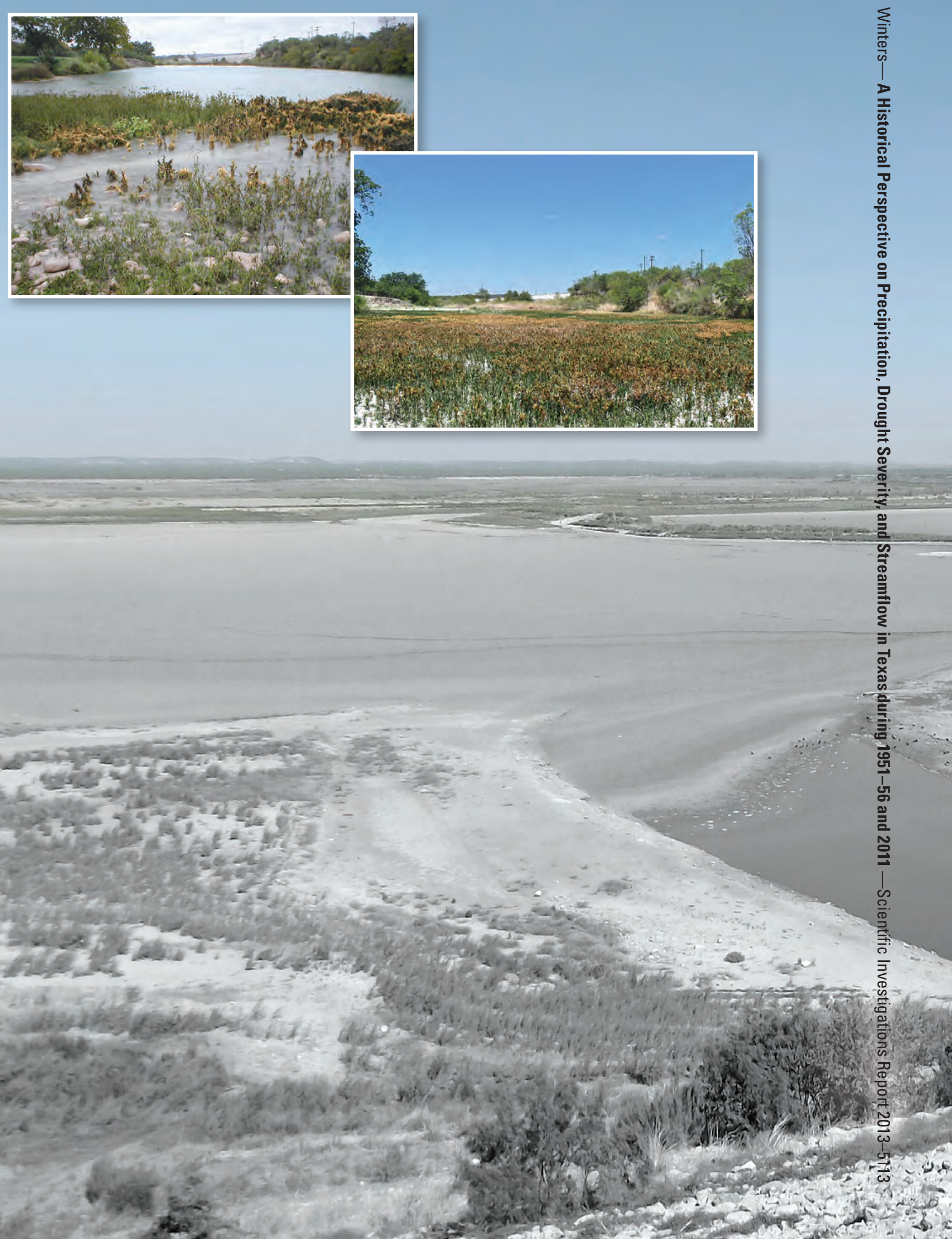